\title{
Stability First, Development Second, Democracy Third: The European Union's Policy towards the Post-Conflict Western Balkans, 1991-2010
}

\author{
SONJA GRIMM \& OKKA LOU MATHIS
}

\begin{abstract}
This article assesses total EU financial flows towards the Western Balkans between 1991 and 2010. It shows that, in the short term, the majority of support has been allocated to humanitarian assistance and socioeconomic development. Although the EU has declared its interest in democracy promotion, democracy assistance ranks only third on the list of its financial expenditures in the Western Balkans. Therefore, although EU financial aid is consistent with official EU programmes, it is inadequate in the post-conflict context of the EU candidate and potential candidate countries that require support for democratisation.
\end{abstract}

SinCE THE 1990s, THE SUCCESSOR STATES OF THE Socialist Federal Republic of Yugoslavia and Albania have been of special interest to the European Union (EU) due to its quest for peace and stability. In order to overcome the consequences of Yugoslavia's violent dissolution and to contribute to the creation of a stable and peaceful neighbourhood, the EU has provided considerable financial and technical support to south-eastern Europe. However, despite this, the recipient countries in the Western Balkans still differ substantially in levels of development and democratisation, as well as in their progress in the EU association and approximation process. ${ }^{1}$

We wish to thank Franziska Blomberg, Lisa Groß and Gerald Schneider, as well as the members of the research network 'External Democratization Policies' for their helpful comments on earlier versions of this manuscript. Generous financial support from the Young Scholar Fund of the University of Konstanz is gratefully acknowledged. All remaining errors are ours alone.

${ }^{1}$ In the process of association, all countries wishing to join the EU must prepare to comply with the Copenhagen criteria, on which the Commission's opinion on any application for accession is based. These criteria were laid down at the European Council meeting in Copenhagen in 1993 and include a political (stability of the institutions safeguarding democracy, the rule of law, human rights and respect for and protection of minorities), an economic (existence of a viable market economy, the ability to respond to the pressure of competition and market forces within the EU) and an aquis (the ability to assume the obligations of a member state stemming from the law and policies of the EU) criterion. The approximation of law means that countries aspiring to join the EU must align their national laws, rules and procedures in order to give effect to the entire body of EU law contained in the acquis communautaire. The acquis communautaire includes the directives, regulations and decisions adopted on the basis of the various treaties which together make up the primary law of the European Union. 
In approaching our topic, we intended initially to assess the EU's development and democratisation strategy for this region in terms of the type and amount of assistance provided by the EU in different sectors. The purpose was to analyse whether and how the EU responds to varying contexts in order to support development and democracy. To our astonishment, initial empirical investigations revealed that neither publicly accessible information nor experts within the EU could provide a comprehensive and detailed list of programmes and projects that have been financially supported over the last two decades. To address this information gap, we therefore decided to compile an empirical dataset of all EU programmes and projects directed at the Western Balkans from 1991 to 2010, systematising all financial flows into seven main components of external aid in post-conflict contexts. This compilation is a necessary first step towards a broader academic impact analysis of both development aid in general and democracy promotion in particular. On the basis of this new dataset, this article assesses the EU's democracy assistance to the Western Balkans in the context of total EU financial flows towards the successor states of Yugoslavia and Albania from 1991 to 2010. We seek to clarify which sectors EU money supports in the Western Balkans in order to reveal patterns that differ across countries and that might indicate the strategy the EU has been using in the region to support democracy-building. To this end, we assume that the EU's sectoral financial commitment reflects its political priorities.

We show that after having first provided humanitarian assistance, the EU has invested primarily in socio-economic development during the last two decades. Democratic institution-building and capacity-building only ranks third on the EU's spending priority list. We deduce that the EU has been using a developmental approach to assist post-conflict recovery in the Western Balkans, namely by supporting socio-economic development to create favourable context conditions for democratisation. A political approach, on the contrary, would have prioritised investing in democratic institution-building and in advancing the empowerment of democratic actors. Furthermore, we demonstrate that while the EU's financial commitments across sectors have been consistent with official EU rhetoric, the EU has not pursued any obvious strategic pattern for distributing aid money in the region. Finally, we discuss whether prioritising developmental over political approaches to democracy promotion is an appropriate means to support post-conflict reconstruction.

The argument develops in three steps. First, we unravel the complex assortment of the various EU framework programmes and instruments devoted to the Western Balkans over the observation period. The disentanglement of the intertwined programmes allows us to identify the main objectives of EU policy in the Western Balkans and the corresponding changes in focus over time. Second, we trace EU spending by component, across countries and over time. We find variance in EU spending not only among the components of democratic governance, security-building, building the rule of law, socio-economic development and political community-building in each country, but also differences between the recipient countries and in each country's progress in the EU association and approximation process. Third, we investigate in particular to what extent the EU has actively invested in the democratisation of the Western Balkans through the instrument of democracy assistance. The EU is, according to its self-understanding, a 'normative power' interested in the worldwide promotion of democracy and human rights (Manners 2002, 2006; Grabbe 2005; Hyde-Price 2006; Pace 2007; Noutcheva 2009). One of the main objectives of EU policy in the region is 'to underpin democracy and the rule of law, human 
rights, civil society and the media' (European Commission 2001, p. 3). ${ }^{2}$ Our assessment reveals that these words are not sufficiently backed up by the respective financial commitments.

This contribution proceeds as follows: the next section orients the research endeavour to current democracy promotion research. The following sections then provide an overview of EU support programmes and their development over time; conceptualise the set of component destinations for financial flows in post-conflict states; present our dataset, and highlight our research findings in the light of current debates on state-building and democracy promotion. The concluding section rounds up the analysis and suggests avenues for further research.

\section{Democracy promotion and democracy assistance in post-conflict contexts}

The intentions of democracy promotion are to foster democratic institution-building and the empowerment of democratic political actors, as well as to contribute to the creation of favourable conditions for democratisation. This entails the following range of instruments of varying intrusiveness: first, dialogue, in which the main mode of influence is role modelling and persuasion; second, democracy assistance, in which influence is primarily exerted by the provision of financial assistance (through non-profit grants) and technical assistance (through consultancy to contribute to democratic capacity-building); third, conditionality (in terms of membership or policy) which exerts influence by means of the implementation of positive and negative incentives to change the preferences of the targeted actors; and fourth, democracy enforcement, in which democratic rule is imposed through military means and externally controlled regime change (Van Hüllen \& Stahn 2009, p. 125; Grimm 2010, pp. 74-7). All these options represent instruments of top-down democratisation through cooperation with the domestic political elite; and additionally, the first and second options include the possibility of bottom-up democracy assistance through the promotion of civil society actors (Carothers 1999, pp. 157-251). These four instruments are not mutually exclusive alternatives. As Burnell notes, international actors are as likely as not to employ a combination of methods, either as part of a planned sequencing strategy or in an incremental or even haphazard manner (Burnell 2000, p. 7).

Carothers (2009) distinguishes between political and developmental approaches to democracy promotion. The political approach proceeds from a 'narrow conception of democracy-focused, above all, on elections and political liberties-and a view of democratisation as a process of political struggle in which democrats work to gain the upper hand in society over non-democrats' (Carothers 2009, p. 5). This approach is based on a lean concept of democracy as first proposed by Dahl (1971). It highlights the importance of genuine, competitive elections and sufficient respect for political and civil rights to ensure that citizens can participate meaningfully in democratic political processes. The developmental approach of democracy promotion, based on a broader notion of democracy

\footnotetext{
${ }^{2}$ See also, 'Communication from the Commission to the Council and the European Parliament on the Stabilization and Association Process for the Countries of South-Eastern Europe', COM 235/1999 final, available at: http://eur-lex.europa.eu/summary/EN/URISERV:r18003, accessed 15 May 2015; 'Communication from the Commission, 2005 Enlargement Strategy Paper', COM 561/2005 final, available at: http://eur-lex.europa.eu/legal-content/EN/TXT/?uri=CELEX:52005DC0561, accessed 15 May 2015.
} 
(comprising civil and political rights as well as social and economic rights), perceives democratisation 'as a slow, iterative process of change involving an interrelated set of political and socioeconomic developments' (Carothers 2009, p. 5).

In post-conflict societies, democracy promoters are confronted with certain special conditions that substantially distinguish democracy promotion in such societies from democracy promotion in more stable and peaceful contexts in which the risk of the violent escalation of conflict is considerably less. In a post-conflict context, the existence of a security dilemma constrains the relationships between the conflicting parties and necessitates the creation of a legitimate monopoly on force as well as comprehensive demobilisation and reintegration programmes for former combatants (Walter 1997, 2004). Short-term humanitarian assistance must be complemented by long-term socio-economic development to address the root causes of conflict (Collier 2000; Ballentine \& Sherman 2004; Collier \& Hoeffler 2004), and to establish an economic foundation that will ensure the survival of the newly created political system (Grimm 2008). As a consequence of violent conflict, state institutions may disappear in what the literature refers to as 'failing' or 'failed' statehood (Rotberg 2004; Chesterman et al. 2005; Coggins 2011; Grimm 2014), thus engendering the need to create or recreate state institutions (Grimm 2010, pp. 90-4). Finally, lost social capital and trust must also be rebuilt in order to create political communities that do not challenge the existence of the state (Linz \& Stepan 1996).

To overcome these problems in the Western Balkans after the dissolution of Yugoslavia, the community of Western democracies has used different combinations of the four democracy-promoting instruments at various stages of the post-conflict recovery. Much has been written about international and EU diplomatic initiatives, such as dialogue, to moderate the consequences of Yugoslavia's violent disruption (Woodward 1995; Calic 1996; Pond 2006). This is also true for the EU's membership and policy conditionality, which can be considered to be one of the best researched democracy promotion tools to date (Schimmelfennig \& Sedelmeier 2004; Anastasakis 2008; Schimmelfennig 2008; Noutcheva 2009; Trauner 2009; Youngs 2011). Democracy enforcement has played an important role, especially in the transitions in Bosnia \& Hercegovina and in Kosovo, and has also been thoroughly examined in research (Chandler 2000; Caplan 2005; Tansey 2007; Zaum 2007; Narten 2008; Gromes 2009; Grimm 2010).

The only democracy promotion tool used in the Western Balkans that has been relatively disregarded is the EU's democracy assistance; this was our reason for examining this instrument. We investigate democracy assistance in terms of the amount and patterns of EU financial flows to the Western Balkans targeted at developing democratic institutions and empowering pro-democratic actors. The provision of advice and instruction, training programmes, and other forms of material support for institutional capacity-building and actor empowerment are typical examples of democracy assistance, as are financial subventions to pro-democracy bodies and subsidies to cover the costs of certain democratisation processes (Burnell 2000, p. 9). Relevant institutions include political rules (such as constitutions and electoral laws), political procedures (elections and legislative voting), and political organs (governments, ministries and parliaments). Actors may be representatives of the government, the public administration or political parties, or representatives of civil society or the public media (Burnell 2000, p. 13; Zeeuw \& Kumar 2006, p. 13). We assume that capacity-building through democracy assistance is a necessary prerequisite for the internal implementation of democratic reforms, for management of the 
disruptive effects of the transition to liberal and competitive political rules, and for the acceptance of EU conditions and their inclusion in national law. Such capacity is also necessary for the management of EU funds and the organisation of projects in the socioeconomic sphere.

In the following analysis, we will argue that the EU's policy towards the Western Balkans generally pursues a developmental approach with a focus on the socio-economic side of democratisation; it thereby overlooks the importance of assistance to the political side, namely the development of democratic political institutions and the empowerment of democratic actors. This oversight can in part explain the slow progress of democratisation in many of the Western Balkan countries.

\section{EU framework programmes for the Western Balkans}

To support the Western Balkan states in their recovery from the violent dissolution of Yugoslavia, since 1991 the EU has channelled assistance through a variety of programmes and financing instruments, ranging from ECHO in times of humanitarian crises to PHARE and OBNOVA for economic restructuring to the integrated all-in-one framework programmes of CARDS and IPA. The bottom-up instrument EIDHR has complemented the use of these top-down instruments in the region. ${ }^{3}$

In the immediate aftermath of the collapse of Yugoslavia during 1991 and 1992, the EU provided humanitarian assistance and disaster relief through the Humanitarian Aid Office of the European Commission (ECHO), later called the European Commission on Humanitarian Aid and Civil Protection (DG Humanitarian Aid). From 1991 to 2000, all of the countries of the Western Balkans received assistance under ECHO through three channels: emergency aid, food aid, and aid for refugees and displaced persons (European Union 2011a). ECHO enabled the EU to engage in humanitarian crises either directly, in close cooperation with key international humanitarian players (such as UN agencies) and non-governmental organisations, or indirectly, through the co-financing of missions led by other international agencies. Up to the year 2000, safeguarding the survival of the population was clearly the EU's priority in the Western Balkans.

Between 1992 and 2006, the Western Balkans benefitted from the programme Poland and Hungary: Assistance for Restructuring their Economies (PHARE). ${ }^{4}$ The original purpose of PHARE was to assist candidate countries in Central and Eastern Europe in 'financing or participating in financing of projects aimed at economic restructuring' (European Council 1989), but also to provide humanitarian assistance (European Council 1990). Later, PHARE was amended to support agricultural development and to assist administrations and institutions in adopting the acquis communautaire (European Council 1999a). With the dissolution of Yugoslavia, the successor countries and Albania gradually became eligible for PHARE

\footnotetext{
${ }^{3} \mathrm{ECHO}$ is the European Community Humanitarian Office that holds a programme under the same name for humanitarian assistance and disaster relief. PHARE, the Pologne et Hongrie: Aid à Restructuration Economique was later renamed the Programme of Community Aid to the Countries of Central and Eastern Europe. OBNOVA was the European Commission's Reconstructing Programme. CARDS is the abbreviation for the Community Assistance for Reconstruction and Development to the Western Balkans that was replaced in 2007 by IPA, the Instrument for Pre-Accession Assistance. EIDHR, the European Initiative for Democracy and Human Rights, was renamed in 2007 as European Instrument for Democracy and Human Rights. For more details on time frames, purpose and means of these financial instruments please refer to Table 1.

${ }^{4}$ Later also called Programme of Community aid to the countries of Central and Eastern Europe.
} 
(European Council 1991). The aim of supporting 'moves ... towards greater democracy' was mentioned in a council regulation for the first time in 1996 (European Council 1996a).

In reaction to the Kosovo conflict in 1999, the international community, ${ }^{5}$ under the leadership of the EU, created the Stability Pact for South Eastern Europe, a framework for conflict prevention and the promotion of inter-regional cooperation and development within the Western Balkans. The Stability Pact represented an integrated framework to assist these countries in achieving objectives set out in three sections: democratisation and human rights; economic reconstruction, cooperation and development issues; and security issues (Stability Pact 2005). With this instrument, the EU recognised its 'responsibility to contribute to the resolution both of the immediate instability and, in the longer term, to the general stabilization and development of the region', motivated by the region's geographic proximity to the EU as well as by the prospect of mutual benefits through regional stabilisation. ${ }^{6}$ The Stability Pact for South Eastern Europe therefore represents the beginning of the EU's political commitment to the region, setting the stage for the Western Balkan countries' potential membership of the Union. In 2008, the Stability Pact was replaced by the Regional Cooperation Council (RCC), in response to the quest for greater autonomy among south-eastern European countries. ${ }^{7}$ The RCC is owned by the countries of the region themselves, with continued support and advice from the international community and thereby more regionally driven than the Stability Pact, which was driven more by outside partners. The RCC now oversees cooperation processes in the Western Balkans and works to enhance regional and European integration.

The Stability Pact was accompanied by a more institutionalised Stabilization and Association Process (SAP) for south-eastern Europe, which was adopted at the 2000 Zagreb summit by the European Council and the heads of state and governments of the Western Balkans. The process offered 'higher incentives to the countries concerned' and required 'compliance with more demanding conditions, both political and economic as well as increased emphasis on the need for regional cooperation'. In addition to the promotion of democracy, administrative structures, and the rule of law, economic development and regional cooperation, 'association-orientated' assistance (such as legal approximation to the EU acquis) played a major role in the SAP. This was the first official document linking EU policy towards the Western Balkans and the process of EU integration. Post-conflict recovery and economic development were to be facilitated by the 'increased assistance for democratization, civil society, education and institution-building'. ${ }^{8}$ This view of democracy promotion as a means rather than as an end in itself would seem to indicate that the EU would subsequently follow a developmental approach in the region.

\footnotetext{
${ }^{5}$ In addition to the EU, which served as the driving force, the Stability Pact for south-eastern Europe further involved the OSCE, UN agencies (such as the UNHCR), the European Bank for Reconstruction and Development, the European Investment Bank, the International Monetary Fund, the World Bank, the North Atlantic Treaty Organization (NATO) and the Western European Union.

${ }^{6}$ C Communication from the Commission to the Council and the European Parliament on the Stabilization and Association Process for the Countries of South-Eastern Europe', COM 235/1999 final, available at: http:// eur-lex.europa.eu/summary/EN/URISERV:r18003, accessed 15 May 2015.

${ }^{7}$ See, Regional Cooperation Council, 2005, available at: http://www.rcc.int/pages/6/2/overview, accessed 1 March 2012.

${ }^{8}$ 'Communication from the Commission to the Council and the European Parliament on the Stabilization and Association Process for the Countries of South-Eastern Europe', COM 235/1999 final, available at: http:// eur-lex.europa.eu/summary/EN/URISERV:r18003, accessed 15 May 2015.
} 
The conditions for obtaining EU candidate status and eventually EU membership are fixed in the Stabilization and Association Agreements (SAAs) between the EU and each individual country. According to these SAAs, the countries should 'begin to prepare themselves for the demands of the perspective on accession to the EU'-namely, by meeting the Copenhagen Criteria for EU membership (European Commission 2011a). The EU's priority areas in the SAP were democratisation, civil society and institution-building, justice and home affairs, and trade. The instruments implemented to achieve these goals have been economic and financial assistance as well as political dialogue. Financial assistance has been provided in the form of grants, loans, balance of payments support and debt relief for countries that were especially affected. In short, the development of marketbased economies has clearly been prioritised over democratic development throughout the SAP regulations and agreements. It is therefore unsurprising that the SAAs define economic cooperation between the EU and each country as a cornerstone of the agreement. $^{9}$

Until 2000, community aid to the Western Balkans was 'set to different sets of procedures, which encumbers management' (European Council 2000). After the Zagreb summit, ECHO and PHARE were replaced by the single framework programme Community Assistance for Reconstruction, Development and Stability in the Balkans (CARDS). Between 2000 and 2006, most of the EU's financial and technical assistance was channelled through CARDS and implemented by the European Agency for Reconstruction. CARDS was designed to 'contribute to the stabilization and association process', and its aid was subject to conditions concerning 'democratic principles, the rule of law, human and minority rights, fundamental freedoms and the principles of international law'. In addition to political and economic requirements, EU assistance from this point on has also been directly designated towards 'the creation of an institutional and legislative framework to underpin democracy' (European Council 2000). CARDS was sub-divided into five priority sectors: justice and home affairs; administrative capacity-building; economic and social development; democratic stabilisation; and environment and natural resources (European Communities 2003). With CARDS, both the Community's political and financial policy towards the region developed more organised long-term goals and became considerably more transparent. Based on the objectives of the SAP, Community assistance was predicated on regional and country strategy papers and on multi-annual and annual programmes for each country (European Union 2007; European Commission 2011b).

Finally, in 2007, CARDS was incorporated into the Instrument of Pre-Accession Assistance (IPA), enabling candidate and potential candidate countries 'to introduce the necessary political, economic and institutional reforms to bring them into line with EU standards' (European Commission 2011c). ${ }^{10}$ All Western Balkan countries currently receive funding through IPA, as by 2010 all have been granted either candidate (Croatia, Macedonia and Montenegro) or potential candidate status (Albania, Bosnia \& Hercegovina, Kosovo and Serbia). IPA conforms to the process of association and approximation and covers five different components. Transition Assistance and Institution Building (Component I)

\footnotetext{
${ }^{9}$ As of May 2015, only Kosovo has not yet negotiated an SAA with the EU. Alternatively, the EU established on 6 November 2002 a Stabilisation Tracking Mechanism designed as a specific association process for Kosovo to promote policy dialogue between the EU and the Kosovan authorities on EU approximation matters.

${ }^{10}$ Assistance under IPA is also extended to Iceland and Turkey as EU candidate countries.
} 
includes assistance for stabilisation, democratisation and the building of a market economy. Cross-Border Cooperation (Component II) funds participation in transnational programmes, such as cooperation between candidate and potential candidate countries (regional cooperation) and cooperation with EU member states. The funding provided under Regional Development (Component III) is aimed at technical assistance and investment in the area of transport, the environment and economic cohesion. Education and training is supported under Human Resource Development (Component IV); Rural Development (Component V) includes assistance for restructuring agriculture and enhancing environmental protection and public, animal and plant health (European Commission 2011c). While the first two components are available to both candidate and potential candidate countries, the remaining three components only apply to countries that have already achieved candidate status. However, since the EU has recognised the need to promote regional cooperation, human capacity-building and rural development in potential candidate countries, funding that should in a strict sense be classified as assistance under Components III, IV and V has been granted to these countries under Component I. All types of assistance may be granted in the form of budget support (with supervision by the EU regarding investments, procurement, contracts and subsidies) or in the form of cooperation (technical as well as advisory assistance) (European Commission 2011c).

In addition to programmes specifically developed for the Western Balkans, the EU has also promoted democracy, human rights and the rule of law in the region since 2000 through the European Initiative for Democracy and Human Rights (European Initiative), renamed the European Instrument of Democracy and Human Rights (EIDHR) in 2007 (European Council 1999b, 1999c, 2006). EIDHR funding is independent of intergovernmental bilateral cooperation agreements and enables complementary bottom-up democracy promotion. It targets third parties such as civil society organisations and non-profit organisations, but also parliamentary bodies and international organisations whose activities or projects match European Commission goals for promoting democracy and human rights (European Commission 2011f).

In analysing these programme descriptions, it is evident first, that the EU's original assistance for the Western Balkans appeared not to follow a coherent strategy with clearly determined long-term goals. In the course of the last two decades, however, the EU's programmes have become increasingly more specific with regard to the sectors and components for which the money has been spent. Across all components, significant finetuning, amplification and systematisation are in evidence (see Table 1).

Second, with regard to assistance priorities, a gradual shift from short-term disaster relief towards long-term socio-economic development, institution-building and democratisation can be observed. Peace and stability have been the primary goals, complemented by economic liberalisation and political reforms intended to further democracy. CARDS was the first programme to specify incentives and a framework for democratisation assistance for the entire Western Balkan region. With the introduction of IPA in 2007, assistance became even more specific and targeted towards the adoption of the acquis to prepare for EU accession. The (rather vague) perspective of EU membership nevertheless paved the way for a long-term developmental approach to democracy promotion in the region, as described by Carothers (2009).

Third, the EU relies to a much greater extent on cooperation with state actors than with non-state actors. EIDHR is the only EU instrument of all those identified that directly allows 
TABLE 1

EU Instruments for Development Aid to the Western Balkans

\begin{tabular}{|c|c|c|c|c|}
\hline Instrument & Full name & Time frame & Purpose & Means \\
\hline ECHO & $\begin{array}{l}\text { European Community Humanitarian } \\
\text { Office }\end{array}$ & Since 1994 & $\begin{array}{l}\text { Humanitarian assistance } \\
\text { and disaster relief }\end{array}$ & Grants \\
\hline PHARE & $\begin{array}{l}\text { Pologne et Hongrie: Aid a } \\
\text { Restructuration Economique/ } \\
\text { Programme of Community Aid to the } \\
\text { Countries of Central and Eastern } \\
\text { Europe }\end{array}$ & 1994-2006 & $\begin{array}{l}\text { Economic reconstruction, } \\
\text { pre-accession assistance: } \\
\text { institution-building and } \\
\text { economic and social } \\
\text { cohesion }\end{array}$ & $\begin{array}{l}\text { Grants and } \\
\text { loans }\end{array}$ \\
\hline OBNOVA & $\begin{array}{l}\text { European Commission's } \\
\text { Reconstructing Programme }\end{array}$ & $1996-2000$ & Reconstruction & $\begin{array}{l}\text { Grants and } \\
\text { loans }\end{array}$ \\
\hline CARDS & $\begin{array}{l}\text { Community Assistance for } \\
\text { Reconstruction and Development to } \\
\text { the Western Balkans }\end{array}$ & $2000-2006$ & $\begin{array}{l}\text { Stabilisation, economic } \\
\text { reforms, regional } \\
\text { cooperation in line with } \\
\text { SAA }\end{array}$ & $\begin{array}{l}\text { Grants and } \\
\text { loans }\end{array}$ \\
\hline \multirow[t]{2}{*}{ EIDHR } & $\begin{array}{l}\text { European Initiative for Democracy } \\
\text { and Human Rights }\end{array}$ & 1994-2006 & $\begin{array}{l}\text { Promotion of democracy } \\
\text { and human rights }\end{array}$ & Grants \\
\hline & $\begin{array}{l}\text { European Instrument for Democracy } \\
\text { and Human Rights }\end{array}$ & Since 2006 & $\begin{array}{l}\text { Promotion of democracy } \\
\text { and human rights, civil } \\
\text { society promotion }\end{array}$ & Grants \\
\hline IPA & $\begin{array}{l}\text { Instrument for Pre-Accession } \\
\text { Assistance }\end{array}$ & Since 2007 & $\begin{array}{l}\text { Pre-accession assistance: } \\
\text { political, economic and } \\
\text { institutional reforms } \\
\text { (across all sectors) }\end{array}$ & $\begin{array}{l}\text { Grants and } \\
\text { loans }\end{array}$ \\
\hline
\end{tabular}

Source: Authors' compilation.

financial support to non-governmental organisations. The majority of programmes are dedicated to ministries and the respective governmental organisations. As a result, EU democracy promotion is very much top-down in nature, oriented towards the establishment of functioning political institutions and an effective state administration. This strategy has not been balanced by an equally weighted bottom-up approach intended to foster a lively political community and a challenging independent civil society.

\section{Seven components of assistance to post-conflict states}

From an analytical point of view, the EU nomenclature for sectors and aid components are too chaotic to allow a comprehensive overview of where EU money has gone over the period of investigation. Changes and dynamics in particular areas of reform over time are incredibly difficult to trace. Thus, to reduce confusion and to introduce scientific clarity, we decided to classify EU financial assistance provided between 1991 and 2010 according to a general scheme first proposed by Grimm (2010). This synthesises findings from the literature on regime change and on state-building and focuses on external contributions to the stabilisation and development of post-conflict states (Grimm 2010, pp. 80-98). Grimm identifies five principle areas of reform in which external actors actively engage in promoting the stabilisation, institutionalisation, and consolidation of a democratic state based on the rule of law and a market economy: security; rule of law; socio-economic development; democratic governance; and political community (see Table 2). In our understanding, aid provided in the context of component 'democratic governance' can be 


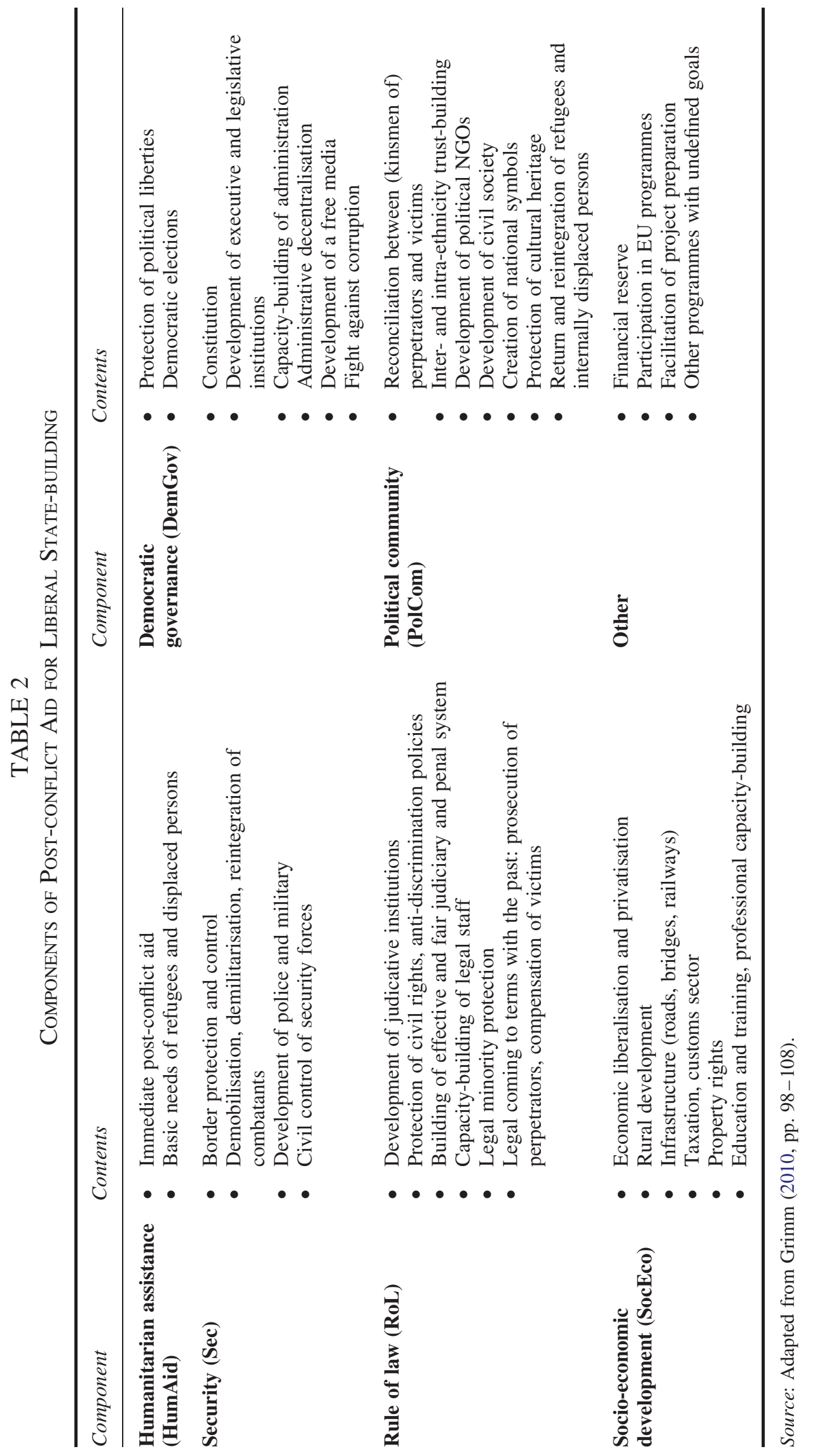


defined as assistance to democratic institution-building and capacity-building. Assistance allocated to the other components indicates support for improving the contextual conditions for democratisation.

In the sector of 'security', political actors seek to build a stable monopoly on the use of force to guarantee the country's internal and external stability, to demobilise combatants, and to institutionalise and establish civil control over the police and the military. Under the 'rule of law', is included the protection of the civil rights of all inhabitants of the territory, and the prohibition of discrimination and vigilante justice. In an effective rule-of-law system, the judiciary (including judges, lawyers, prosecutors and all other judiciary staff) must be independent and impartial. A functioning system of civil, administrative and criminal law including the respective courts must be established. Coming to terms with the past-including the juridical investigation of past offences, the prosecution of perpetrators, and the rehabilitation and compensation of victims - also belongs to this category.

In the sector of 'socio-economic development', political actors seek to establish a prosperous market economic system with considerable economic growth rates and high employment. Such a process includes the development of infrastructure, the liberalisation of economic rules, the privatisation of formerly state-owned enterprises, the development of small and medium-sized enterprises, and rural development. It also entails the introduction of a commonly accepted tax system and the creation of rules for the fair distribution of welfare. Structural programmes in this sector seek to improve the employability of workers through education and training. In addition, in a post-civil war situation, property rights require special attention in order to fairly address past inequities while still encouraging future growth.

With regard to 'democratic governance', political rights should be implemented and guaranteed. To this end, a constitution based on institutionalised checks and balances and the horizontal and vertical accountability of the government and a corresponding legal code must be drafted and implemented. Free and fair democratic elections must be held to select political representatives, and rules for everyday decision-making must be established. Programmes investing in the formation and capacity-building of political actors (such as, political parties, political unions, members of parliament, members of the government and public administration, and voters) belong to the sector of democratic governance. Democracy promoters active in this sector might also support financially the decentralisation of public governance and the strengthening of the autonomy of municipalities. The development of a free media and human rights and democracy education further contribute to the development of democratic governance.

In developing a 'political community', aid programmes support the foundation of a functioning political system. Without a shared sense of belonging to a single political community, the inhabitants of a territory may find it difficult to accept decisions taken by their government. In the worst case, they may question the survival of the state. A political community is also necessary in order to decide who are citizens and are therefore allowed to vote and to be elected. This aspect includes reconciliation, trust-building, and the enhancement of cooperation between and among groups in the society, as well as the creation of national symbols and the reinforcement of the society's cultural heritage. The promotion of a lively civil society also falls into the category of political community-building.

The majority of EU aid can be assigned to one of these five categories. An addition to our dataset was the sixth category of humanitarian assistance. The financial aid provided 
through ECHO in the early years of EU engagement in the Western Balkans primarily targeted the basic humanitarian needs of refugees and civilian victims of the civil wars. We did not find that ECHO money was spent in any of the other five categories.

Finally, as a seventh category, we included 'other', which encompasses all financial aid provided as an annual financial 'reserve', aid that supports 'participation in EU programmes' or facilitates 'project preparation' through 'technical assistance', and aid flows labelled as 'specific actions' (see Table 2).

Although these definitions for each of the components are quite clearly drawn, we are also aware of the interwoven nature of the categories. For example, drafting a democratic constitution is not only an act of democratic institution-building, but also entails a rule-oflaw component; the prosecution of war crime perpetrators is not only an important function of the rule of law, but also contributes to post-conflict reconciliation between former adversarial ethnicities; and the capacity for internal financial control is not only important for socio-economic development, but also requires improvement in the country's capacity for democratic governance. Consequently, we found a number of projects and programmes that simultaneously support the development of two or three components. For example, in many cases support for socio-economic development such as infrastructure enhancement was closely linked to improvements in the administrative capacity to organise such projects and to control the investment of funds. In cases of doubt, we carefully investigated the project fiches and then decided to classify the project or programme into the category of its most dominant component.

\section{Data collection}

To examine the distribution and the patterns of EU financial assistance to the Western Balkans in the period between 1991 and 2010, we required an overview of all EU financial contributions to Albania, Bosnia \& Hercegovina, Croatia, Macedonia, Kosovo, Montenegro and Serbia. ${ }^{11}$ We excluded the Yugoslavian successor state Slovenia; in light of the absence of violent conflict after Slovenia's declaration of independence and the country's smooth transition to democracy, the country's experience cannot truly be labelled a post-conflict transition (Bukowski 1999; Cerar 2001; Bebler 2002). We collected information on the financial flows to all selected countries across all sectors of EU assistance through all EU framework programmes listed above.

As the EU itself does not provide a comprehensive and detailed dataset covering all financial flows from the EU to the Western Balkans over the research period, we had to compile a dataset of our own. We extracted the data from information available on EU websites, such as that found in regional and country strategy papers, annual programmes, and progress reports. For the websites, we checked the internet presence of the European Commission Directorate General on Enlargement, the European Commission Directorate General on Development and Cooperation, the former European Agency for Reconstruction (European Agency for Reconstruction 2001-2008; European Commission 2011d, 2011g), and the Delegations of the EU to the Western Balkan countries (European Union 2011b).

\footnotetext{
${ }^{11}$ In most of the EU documents, data for Montenegro and for Kosovo were listed separately even before the state dissolution of Serbia and Montenegro in 2006 and Kosovo's declaration of independence in 2008. When we found only one figure, we attributed this solely to Serbia. Thus, some figures for Serbia may also include assistance to Montenegro and/or Kosovo; this could slightly distort the overall figures.
} 
In addition, we consulted EU and European Commission staff for more detailed information.

It should be noted here that EU documentation of financial aid flows to the Western Balkans leaves a great deal to be desired. With the exception of the data on IPA, information on programmes and spending is scattered across many different websites of the EU and appears apparently arbitrarily in different types of reports. It is at times detailed, but at other times provides only rough figures. In some cases, different sources report contradictory numbers for accumulated annual spending within individual countries for the period ending in 2000. This demonstrates that even within the European Community, early expenditures under the ECHO and PHARE programmes remain rather obscure. To reduce uncertainty and improve robustness, the data compiled have been crosschecked with experts from the DGs Enlargement, Development, and Humanitarian Aid, from the Delegations of the European Commission to the countries, and from the German Foreign Ministry. Due to constant changes in the staff of these organisations, none of these experts had a comprehensive view of where all this EU money had gone over the past 20 years.

Moreover, the numbers in our dataset vary at times substantially from those listed by the OECD Development Assistance Committee (DAC) about financial commitments of the EU in the Western Balkans (OECD 2013). However, the figures are barely comparable: firstly, the OECD DAC displays commitments from all 'EU Institutions', whereas our data are restricted to commitments from the European Commission. Therefore, we only consider funding that comes entirely and exclusively from the general EU budget. Hence, additional financial contributions from individual EU member states are not included. Secondly, it remains unclear from where the data used in the OECD DAC list originate and how potentially contradictory information by different EU institutions is dealt with. Lastly, the OECD DAC only provides figures for the period between 2006 and 2010 (OECD 2013). This limited time frame does not allow for a comprehensive comparison between the different datasets. ${ }^{12}$

Our final dataset includes project and programme titles, the respective EU framework financing instrument (such as ECHO, PHARE, CARDS, IPA), and the amount of funding in millions of Euros. ${ }^{13}$ The compiled figures in our dataset display EU financial commitments in the respective years, but not actual expenditure. This allows identifying EU funding priorities whereas actual expenditure could be distorted by a lack of local capacity to spend aid money or by local will to see money invested in areas of reform where external and domestic preferences do not coincide (Gross \& Grimm 2014). In fact, actual expenditure would tell more about implementation challenges instead of the donor's preferences and priorities that are better displayed in figures on financial commitments. Our dataset provides information on the implementing agency and the beneficiaries of aid, which are to a great extent the ministries in the respective countries and to a lesser extent media outlets and civil society organisations.

\footnotetext{
${ }^{12} \mathrm{We}$ did our best to utilise this expertise in compiling what is to our knowledge the most complete and thorough overview of expenditures in the region. Nevertheless, gaps in the data may still exist. We are very grateful to those experts who spent time going through the data and allowed us to profit from their wisdom and experience. Expert input was collected with a guarantee of anonymity.

${ }^{13}$ The year of the contract does not necessarily coincide with the timeframe of the implementation of the project. If the reports mention a two-year time frame, we split the amount of money in half, allocating half to each of the two years.
} 
We found the most detailed information on how and where money was spent for IPA; the CARDS documentation was less accurate with regard to concrete projects and recipients of the funding. Here, for some years, only accumulated figures by EU component are available. The money allocated under PHARE was the least transparent: in some cases, it was not even clear for which area of assistance this funding was intended. Since PHARE primarily targets economic reconstruction, we included these figures under the socio-economic development component. As we are interested in the EU's spending on democracy assistance, we also planned to include grants falling under EIDHR, which is explicitly devoted to the development of democracy and the protection of human rights. However, we did not find reliable data for all countries and over the complete research period, as published data generally only indicate a total sum for the entire region. Thus, for pragmatic reasons, we decided to exclude EIDHR grants from our calculations.

Finally, it should be noted that the EU also promotes inter-regional cooperation between all neighbouring countries in the Western Balkans on a relatively equal basis. However, we did not include figures and calculations for cross-border cooperation programmes (IPA Component V), since we only found data for the well-documented period from 2007 to 2010. Moreover, we did not consider EU assistance in the form of macro-financial assistance or debt relief, because this information was not available for all countries.

Based on these parameters and on additional information that we drew from the respective project fiches, we categorised each programme or project according to our seven aid components.

\section{Tracing EU financial assistance to the Western Balkans: general findings}

The literature on state-building, development cooperation and democracy promotion raises doubts over whether a single donor with scarce resources can develop a comprehensive strategy encompassing all tasks necessary for post-conflict reconstruction (Grävingholt et al. 2009). Given that post-conflict recovery takes place in a context of scarce financial and personal resources and under immense time pressure, Grimm and Leininger (2012) theoretically identified four options available to external actors for addressing these problems: no action; prioritisation; compromise; and sequencing. In our context, 'no action' would mean that the external actors do not deal with a certain issue; rather, they simply ignore it. In the case of 'prioritisation', external actors prefer one policy goal to another one. In the extreme case, the goal that is considered less important might be abandoned completely. External actors use the option of 'compromise' when several sub-objectives in providing aid are undertaken in parallel; consequently, the expectations of what can be achieved are reduced. The fourth option is 'sequencing', whereby goals are ranked in the order in which they will be addressed. One objective is addressed first before the focus turns to another.

In contrast to our expectations based on the scarcity of resources, 'no action' has never been an option for the EU in the region. By our calculations, in the period from 1991 to 2010 the EU spent in total €11.84 billion in the selected Western Balkan countries. We found evidence that aid money went to all components over the entire period of our investigation; however, total contributions to the socio-economic development component nearly equalled the contributions to all other aid components put together (see Figure 1).

The special conditions of a post-conflict society, as discussed above, render it plausible that for post-conflict recovery in the immediate aftermath of a violent conflict, donors would 


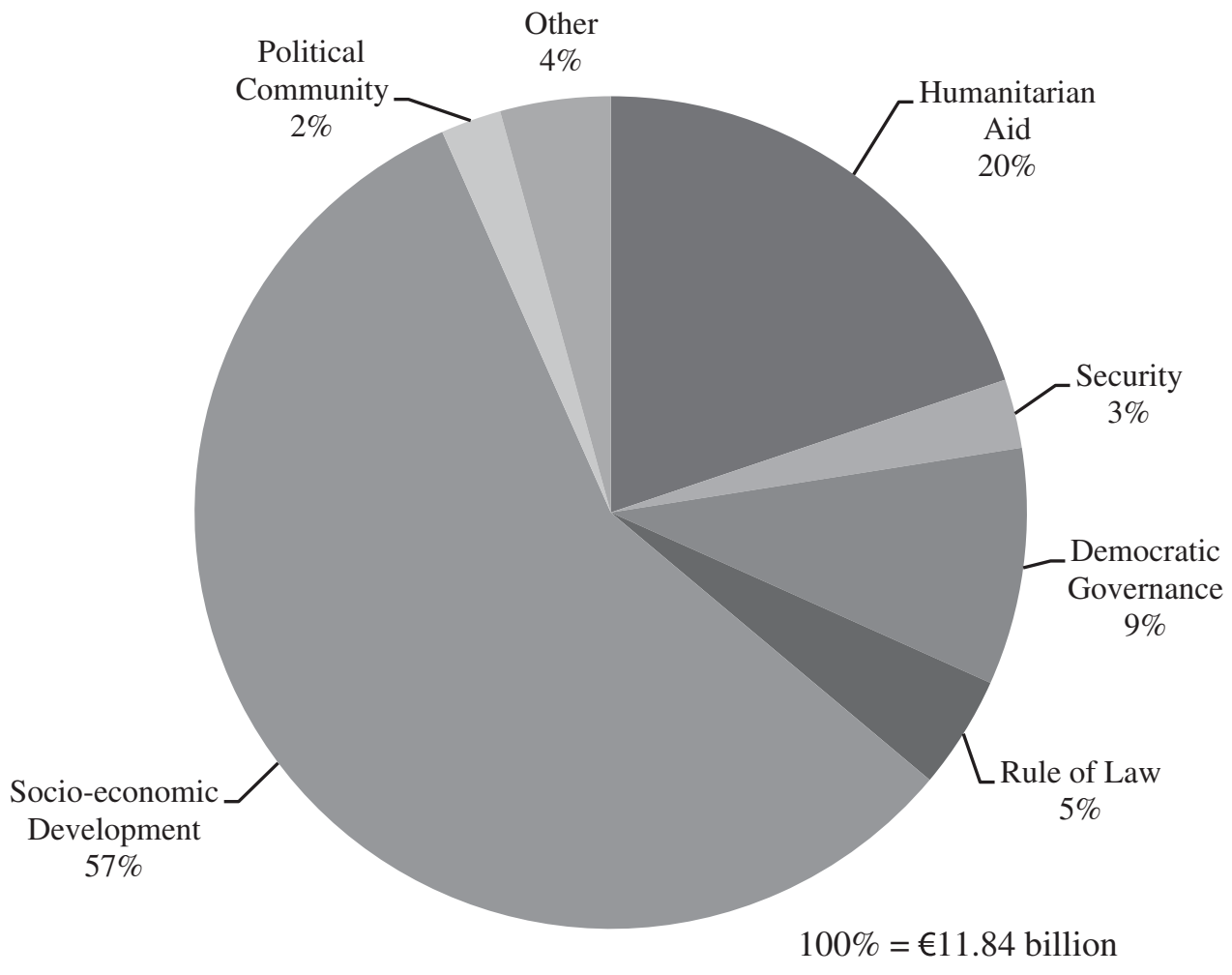

FIGURE 1. EU AssistanCE TO THE WeSTERn BALKANS, 1991-2010. Source: Authors' compilation and calculations.

use sequencing and prioritisation strategies. In a post-conflict setting, external actors would first invest in creating a legitimate monopoly on the use of force, demobilising and disarming combatants, and offering humanitarian emergency assistance to civilians. When a legitimate monopoly on force has been achieved and the most crucial humanitarian needs have been addressed, long-term objectives of post-conflict recovery can come into play (Grimm 2008). In accordance with Spanger and Wolff (2007), we presume that because of scarce resources, donors will prioritise their long-term efforts, dependent on certain (more or less) explicit policy goals or interests. Several goals or interests can be imagined: if the donor identifies itself as a democracy promoter, we would expect to see money being primarily invested in the development of democratic governance, that is, in the construction of democratic institutions and the formation of domestic actors capable of shouldering a democratic transition. If the donor is more interested in access to developing markets, we would expect to see larger investments in socio-economic development: in economic liberalisation and privatisation, infrastructural programmes, and education. If the donor is mainly interested in ensuring a stable and functioning state, we would expect to see money invested in rule of law-building. If the donor is identified with political community-building, we would expect to find most of the money invested in reconciliation, trust-building and civil society development (see Figure 2).

As expected, we found evidence for the use of sequencing and prioritisation in our selected cases: humanitarian assistance was one of the two areas in which the EU spent money in the Western Balkans right from the start. This area had its peak during and in the 
Million $€$

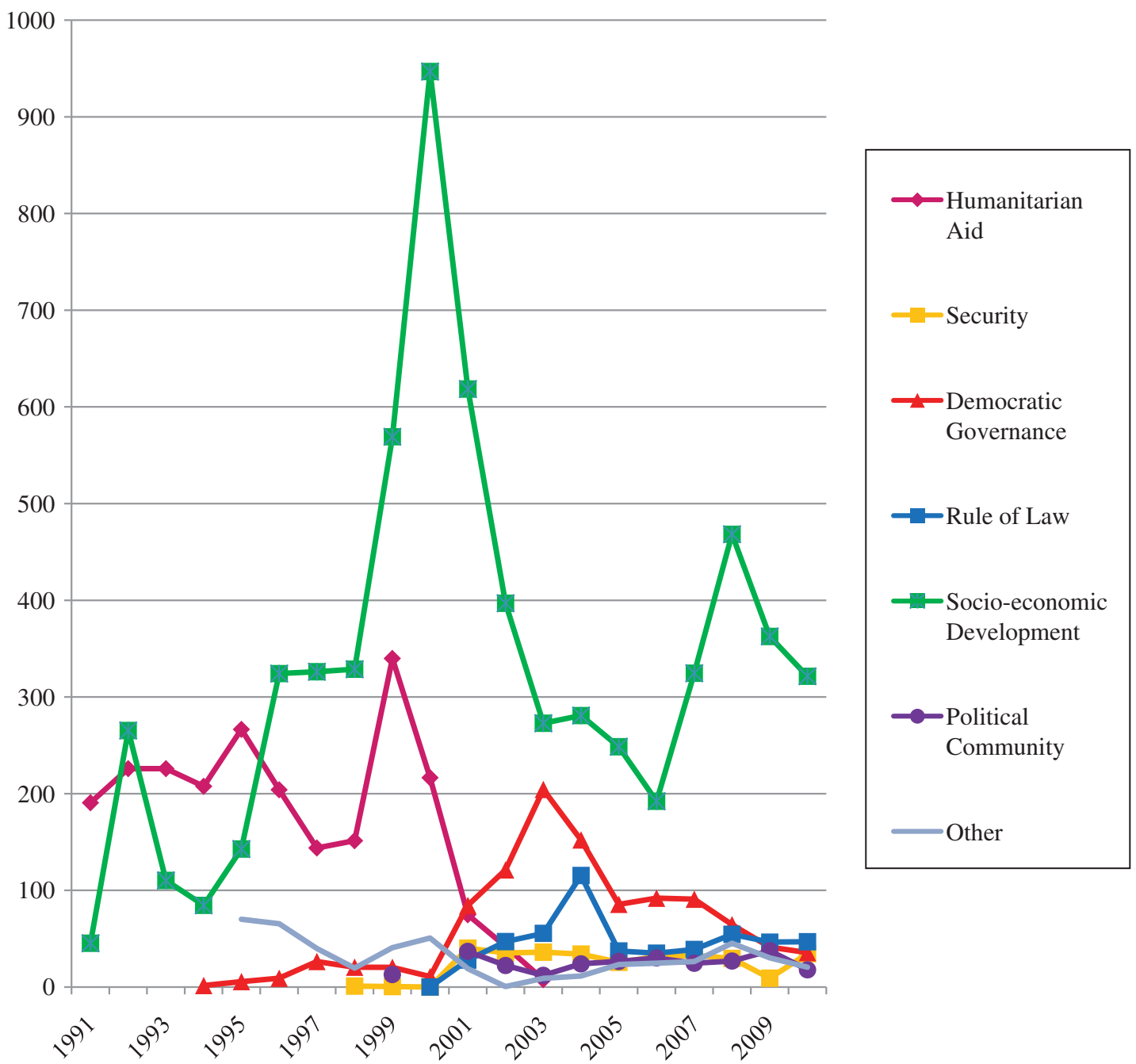

FIGURE 2. ANNUAL EU ASSISTANCE BY COMPONENT AND YEAR TO THE REGION, $1991-2010$.

Source: Authors' compilation and calculations.

immediate aftermath of the signing of the Dayton General Agreement for Peace in 1995. This form of aid supply was finally ended in 2003, when even Kosovo had emerged from the initial period of post-conflict recovery. In contrast to our general expectations, however, humanitarian assistance was accompanied by substantial investment in socio-economic development from the start. As has been noted, except for a short period in 1994-1995, spending for socio-economic development trumped the expenditures for all other components over the entire research period. Two lows can be seen during the Kosovo war (1998-1999) and in a time of a certain aid fatigue (2004-2006); the highest peaks are in 2000, the year of the Zagreb submit, and in 2008, the year in which Kosovo declared its independence and Serbia and Bosnia \& Hercegovina were granted the status of potential candidates for EU membership. Thus, even from the very beginning, the EU was quite interested in the improvement of the socio-economic situations of recipient countries in this region. 
Aid spending to all other assistance components followed consecutively: assistance to democratic governance began in 1994, security-building in 1998, rule of law-building in 1999, and political community-building by our definition and calculations as late as in 2001. The development of spending for the democratic governance component corresponds with our findings in the third section, in which we presented an overview of changes in the framework programmes. From 1994 onwards, spending in this component constituted part of the financial flows, but remained at a rather low level until 2000. It increased considerably after this date, most notably after the Zagreb summit at which the EU officially committed to the democratisation and integration of the region. In accordance with this commitment, the EU augmented aid provisions aimed at democratic governance. The same is true for the rule of law component, which became more important than democratic governance from 2006 onwards, as all countries made progress in their transition to democracy. In comparison, investment in political community-building has only recently been provided, and its level of funding has remained relatively low over the entire period of investigation.

Security-building expenditures as part of the EU development policy remained rather low over the entire research period. However, the literature on state-building especially stresses the problems of building a legitimate monopoly on the use of force in a post-conflict setting (Walter 1997, 2004). Indeed, the EU did not neglect security-building, but cooperation within this field is carried out within the framework of the Common Security and Defence Policy (CSDP). As these missions are financed by member states and not from the EU budget, we did not include this information in our dataset about EU development aid. In addition to security-building by individual EU member states, other actors (such as NATO) have been involved in this issue, allowing the EU to restrict its expenditure. We therefore interpret our data on security-building as a sign for burden-sharing and division of labour among all donors involved in the region's post-conflict reconstruction.

To sum up, across the region, the EU has prioritised socio-economic development over all other aid components. In order of policy implementation, humanitarian assistance preceded socio-economic development and democracy-building; support for the rule of law and political community-building were only recently implemented as EU policies. A clear priority for the support of socio-economic development emerges when comparing the amounts of aid across all sectors.

\section{Findings concerning country patterns across all components}

Given relative resource scarcity and certain political interests of donors, one might predict that evidence for a certain pattern of aid by country would be found-beyond the temporal order discussed in the previous section. In accordance with the idea of 'anchor countries' as important drivers of regional change (Stamm 2004; Altenburg \& Leininger 2008), donors might hope for positive spill-overs or stabilising effects from a selected country provided with particular financial assistance to its neighbours. ${ }^{14}$

\footnotetext{
14،Anchor countries' (a term first proposed by Stamm (2004) and then further developed by Altenburg and Leininger (2008)) comprise the largest economies of each of the developing regions as defined by the World Bank (Stamm 2004). The term highlights economic weight in regional and global terms, regardless of the country's level of development. The anchor countries' relative economic weight in the region is expected to generate strong economic and political spill-overs and goes along with a significant regional, and sometimes also global, political role (Altenburg \& Leininger 2008, p. 5).
} 
Several options are theoretically available. If an external actor is interested in regional security, it will give the most support to the candidate most likely to experience renewed violent conflict. If the EU had followed this pattern, it would have invested most heavily in the stabilisation of Bosnia \& Hercegovina and Kosovo. If the EU had been interested in conflict prevention, Albania would have received most of the money, as the international community would have sought to prevent the spread of the Yugoslav dissolution wars. If an external actor seeks to support stability, it will provide the most support to the most relevant geostrategic candidate. In this case, in our sample, Serbia would have received the majority of funding, as it is politically the most dominant player in the region. However, if an external actor is interested in inciting a positive spill-over effect through quick democratisation, it will invest in the candidate that promises the smoothest democratic transition. According to modernisation theory, high socio-economic development serves as a favourable context for democratisation (Przeworski \& Limongi 1997; Acemoglu et al. 2009). If this had been a relevant factor for the EU, we would have found evidence that Croatia had received most of the funding, as it was (apart from Slovenia) the most economically advanced country in the early 1990s.

A closer look at country profiles indeed supports the assumptions on country variation, but does not allow identification of any one general preference pattern. As Figure 3 reveals, in absolute terms, most of the money was allocated to Albania, Serbia and Kosovo, although the variance between and within the countries over time and spending areas is remarkable (see Figures 5 and 6).

Thus, one can assume a certain context sensitivity on the part of the EU; the EU decided to give most of the financial aid to Albania, as a country that needed protection against the escalation of conflict, and to Kosovo and Serbia, as the countries that were most heavily involved in violent conflict. However, Bosnia \& Hercegovina, a country that was equally mired in violent conflict, received in absolute terms less money than Croatia. In this case, the EU deviated from the conflict prevention and management approach that prioritised support to Albania, Serbia and Kosovo.

In line with our general findings on the sequence of aid, all countries first received humanitarian assistance and socio-economic development; assistance to the other components came later. Most of the funding was allocated to the socio-economic development component; given the total amount of aid to each country, Albania profited more than average from this type of financial flow. Concerning short-term support with regard to humanitarian assistance, the country profiles vary considerably. Here, Albania, Serbia and Croatia rank at the top of the chart, well above Kosovo and Bosnia \& Hercegovina. With regard to longer-term state reorganisation, the EU varied its priorities: democracy assistance was provided especially to Serbia, Bosnia \& Hercegovina and Croatia, while Kosovo, in contrast, benefited most from assistance to the rule of law component. In the former case, the EU supported democratic institution-building; in the latter case, it favoured rule of law-building. All in all, Macedonia and Montenegro received the least assistance in all components.

The picture changes notably if one considers aid flows standardised per capita per country over the entire funding period (see Figure 4$){ }^{15}$

\footnotetext{
${ }^{15}$ We also calculated aid flows per capita per country over each country's funding period, as not all countries received money over the complete period of 20 years. However, this did not significantly change the differences between the countries.
} 


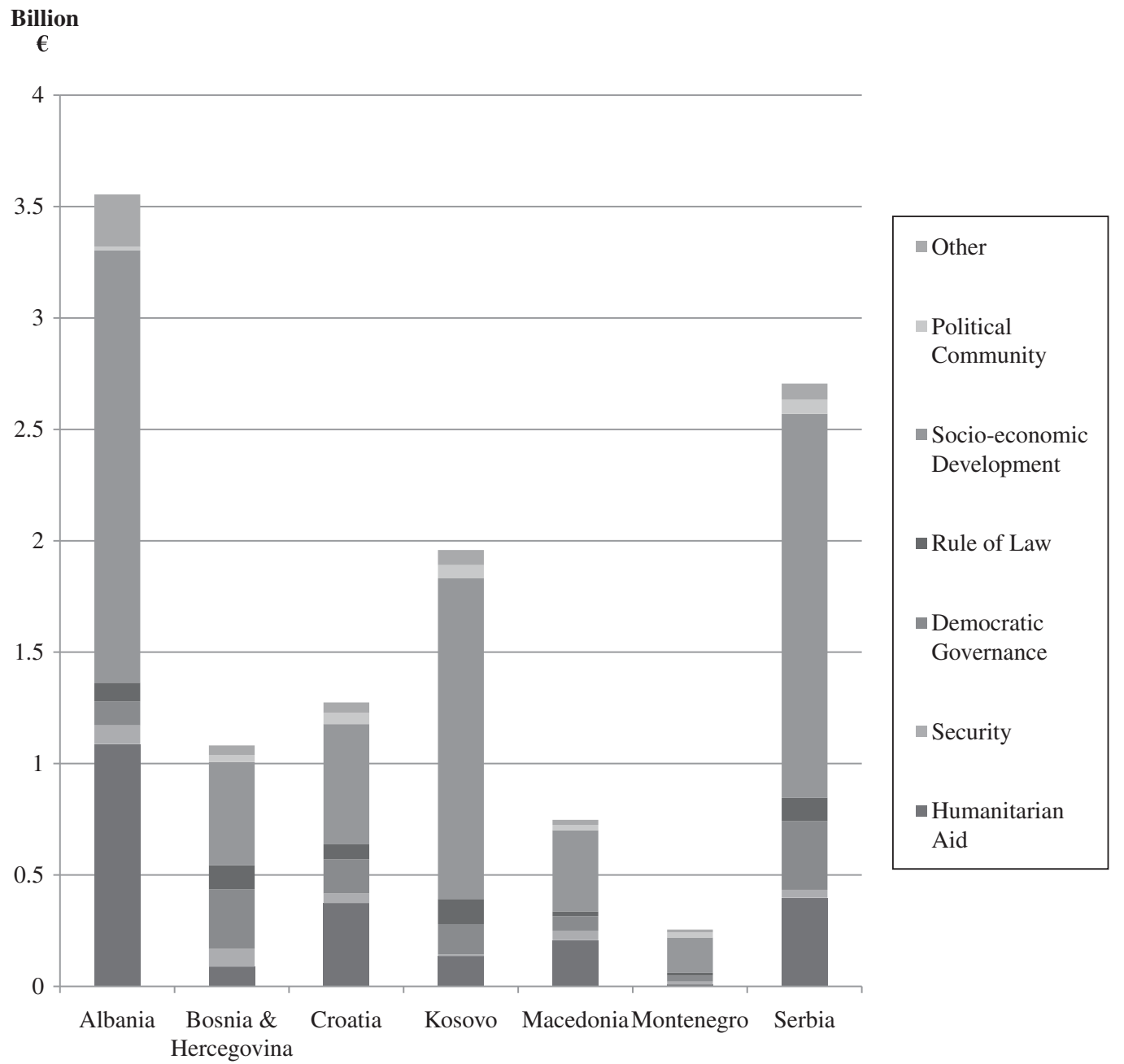

FIGURE 3. EU ASSISTANCE PER COUNTRY AND COMPONENT, 1991-2010. Source: Authors' compilation and calculations.

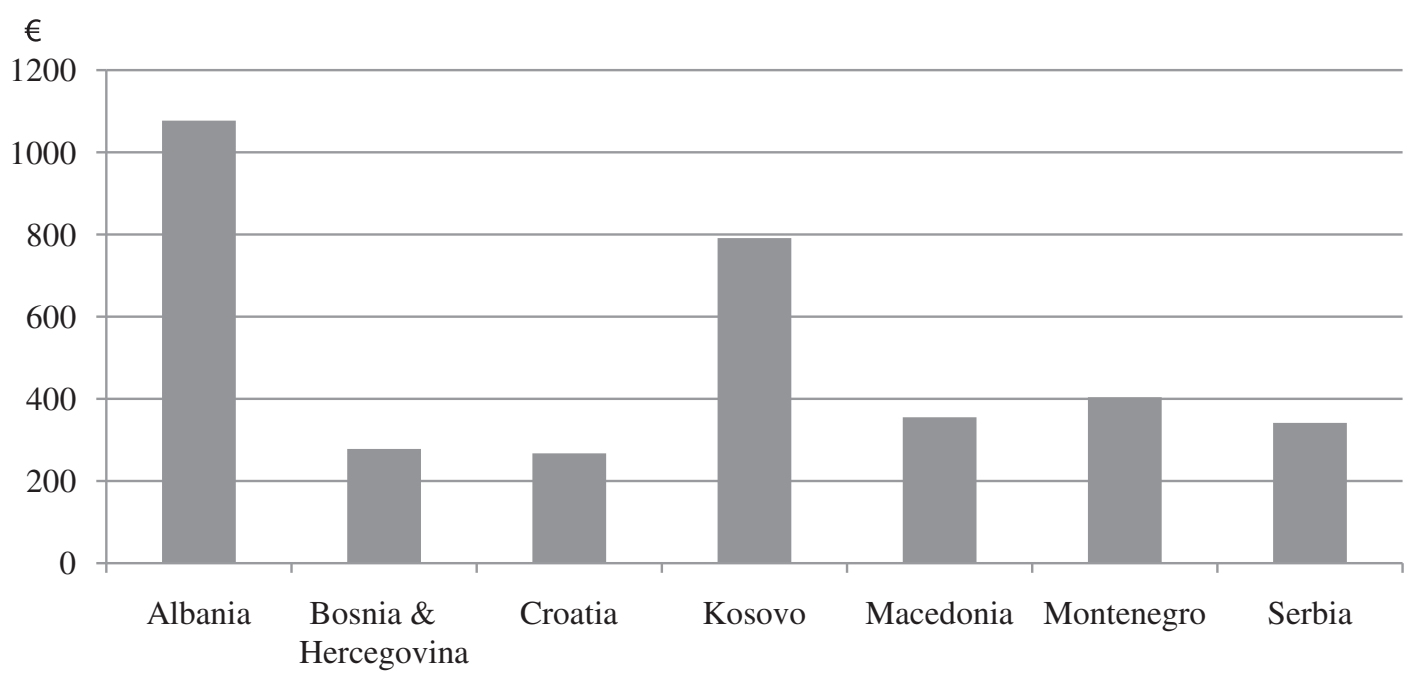

FIGURE 4. EU ASSISTANCE PER CAPITA, 1991-2010.

Note: Based on population averages. Source: Authors' compilation and calculations. 
This calculation again reveals Albania at the top, receiving per capita the most EU funding; all the other countries clearly lag behind. Kosovo received the second largest amount of assistance per capita; Macedonia, Montenegro and Serbia rank third. Surprisingly, Bosnia \& Hercegovina, the most conflict-prone country, and Croatia, the EU integration forerunner, received per capita the lowest amount of financial assistance. The EU has failed to act consistently, either in support of the most conflict-prone country or in support of the socio-economically most promising candidate.

In our dataset, it is further evident that individual countries did not receive money devoted to each component over the entire research period. Here, we found evidence for prioritisation and sequencing approaches. To begin with the then candidate countries, both Croatia and Macedonia received humanitarian assistance from the start; in the former case, this aid was followed by assistance to socio-economic development, while in the latter case, socio-economic assistance was provided in parallel. Montenegro received humanitarian assistance only in 2001 by our calculations, but was provided socioeconomic assistance over the entire funding period; between 1999 and 2010, a large proportion of the country's aid was in the form of socio-economic development assistance (see Figure 5).

One might assume that in the long run, financial flows would rise in countries that have been rewarded with candidate status, because the EU will seek to support the accession process and the integration of the aquis communautaire into national law, and because the countries have demonstrated their capacity to manage large amounts of EU funding. For Croatia, which became a candidate in 2004, this assumption holds true. The total amount of assistance consistently increased during the 2000s and rose particularly high in 20072009. From 2002 to 2004, before awarding the country candidate status, EU aid focused on democratic capacity-building in particular. After 2004, assistance to socio-economic development took the lead in the Croatian funding portfolio, in order to prepare Croatia to compete in the European Single Market. However, funding to Macedonia did not follow this pattern; rather, immediately before being awarded candidate status in 2005, total funding to Macedonia decreased. After this date, the amount of funding has never again reached the peak of the period 1999-2001. At this time, violent tensions had escalated in Macedonia and the international community was engaged in negotiating a peace agreement (finally achieved in 2001 with the 'Ohrid Framework Agreement'). ${ }^{16}$ Thus, in the Macedonian case, the EU devoted particular support to short-term conflict management, but seems to have been less engaged in long-term accession preparations. Montenegro demonstrates a different pattern altogether. Total assistance constantly showed a slight increase from 2000 to 2010. The proportion of socio-economic development was consistently high in comparison to other components. In contrast to the Croatian funding pattern, democracy assistance was provided to a minor extent before candidate status was awarded in 2007, but to a larger extent afterwards. In summary, in the Croatian and Macedonian cases, the countries received more funding after being awarded candidate status than before. In terms of democracy assistance, in accordance with our expectations, Croatia received funding before being awarded candidate status; however,

\footnotetext{
${ }^{16}$ The Ohrid Framework Agreement was the peace deal signed by the government of Macedonia and ethnic Albanian representatives on 13 August 2001. The agreement ended the armed conflict between the National Liberation Army and the Macedonian security forces and set the groundwork for improving the rights of ethnic Albanians.
} 

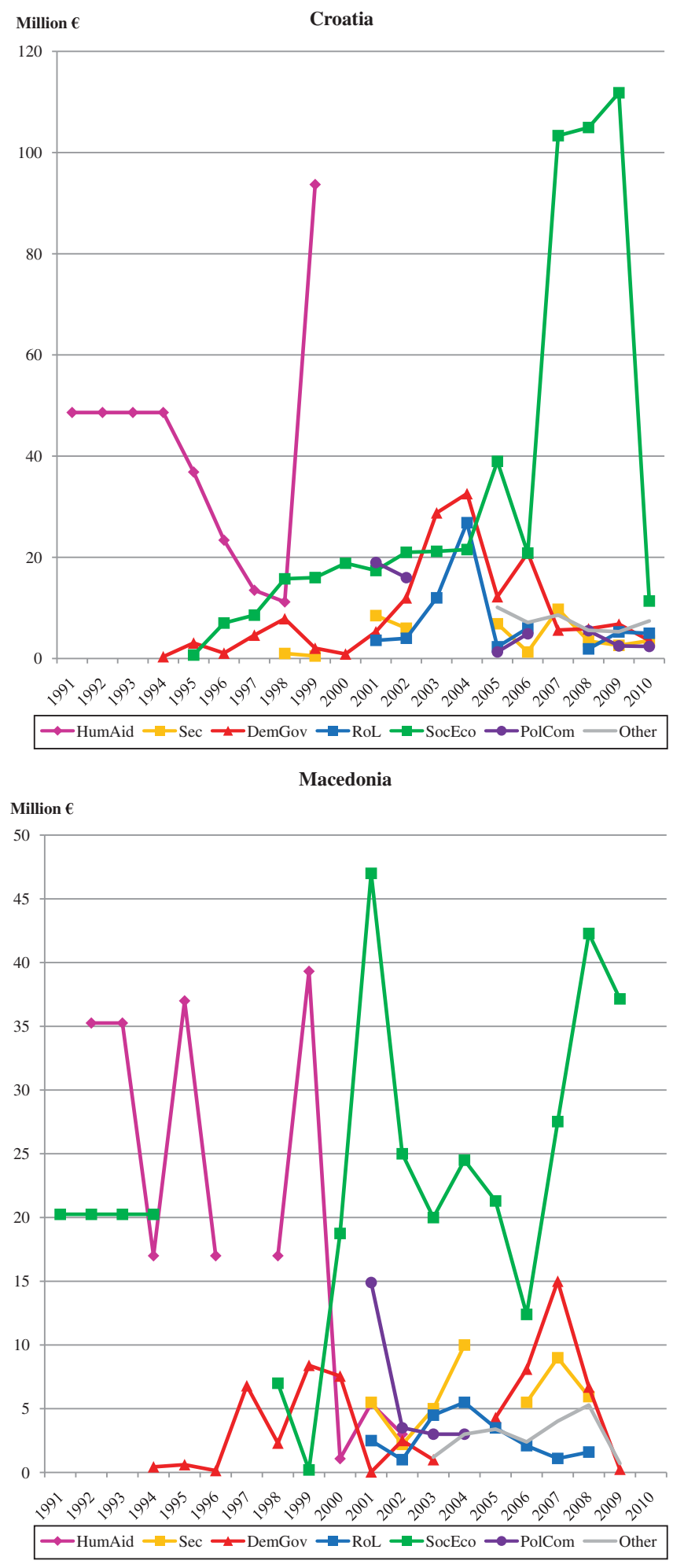

FIGURE 5. 


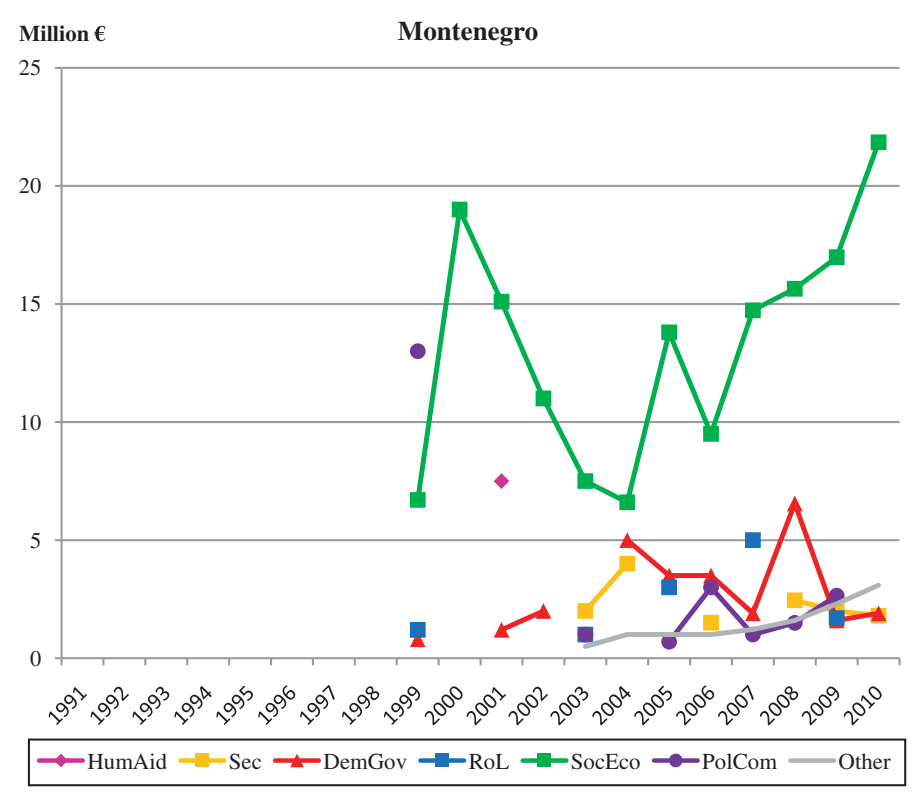

FIGURE 5. EU ASSISTANCE TO CANDIDATE COUNTRIES. Source: Authors' compilation and calculations.

Notes: HumAid—Humanitarian assistance; Sec—Security; RoL—Rule of law; SocEco-Socio-economic development; DemGov—Democratic governance; PolCom—Political community.

Macedonia and Montenegro received significant democracy assistance only after candidate status was awarded. Apparently, the EU considered democracy assistance to the latter two candidates necessary, even though according to the Copenhagen criteria, potential candidates should possess a functioning democracy before they are awarded candidate status. In light of this finding, the EU seems to not take its own criteria for accession very seriously (see Figure 6).

With regard to the potential candidate countries, funding patterns contradict the assumptions and findings presented above. First, in all four cases, humanitarian assistance was provided right from the start, but always in parallel with a considerably larger sum earmarked for socio-economic development. Thus, the EU's second funding focus in the potential candidate countries was socio-economic development. Second, in contrast to the trend shown in the candidate countries, spending for socio-economic development reached its peak in the 2000s. Only in the case of Bosnia \& Hercegovina has socio-economic spending increased again since 2006. Third, assistance for democratic governance was overall higher than such assistance to the candidate countries (see Figures 7 and 8). Finally, the total sum of funding has consistently decreased in all four cases since 2000-an astonishing finding, if one considers the fact that in this year the Union officially committed to the association and approximation of all Western Balkan countries to the EU. All in all, for the potential candidates, one can observe 'smoother' graphs than for the candidate countries.

In summary, our data indeed demonstrate variations between countries, but do not allow the identification of any strategic funding patterns. Even the idea that financial flows would rise in countries given candidate status only holds true for then candidate Croatia, not for the other two candidate countries. Most astonishing is the fact that the total sum of funding in 
938
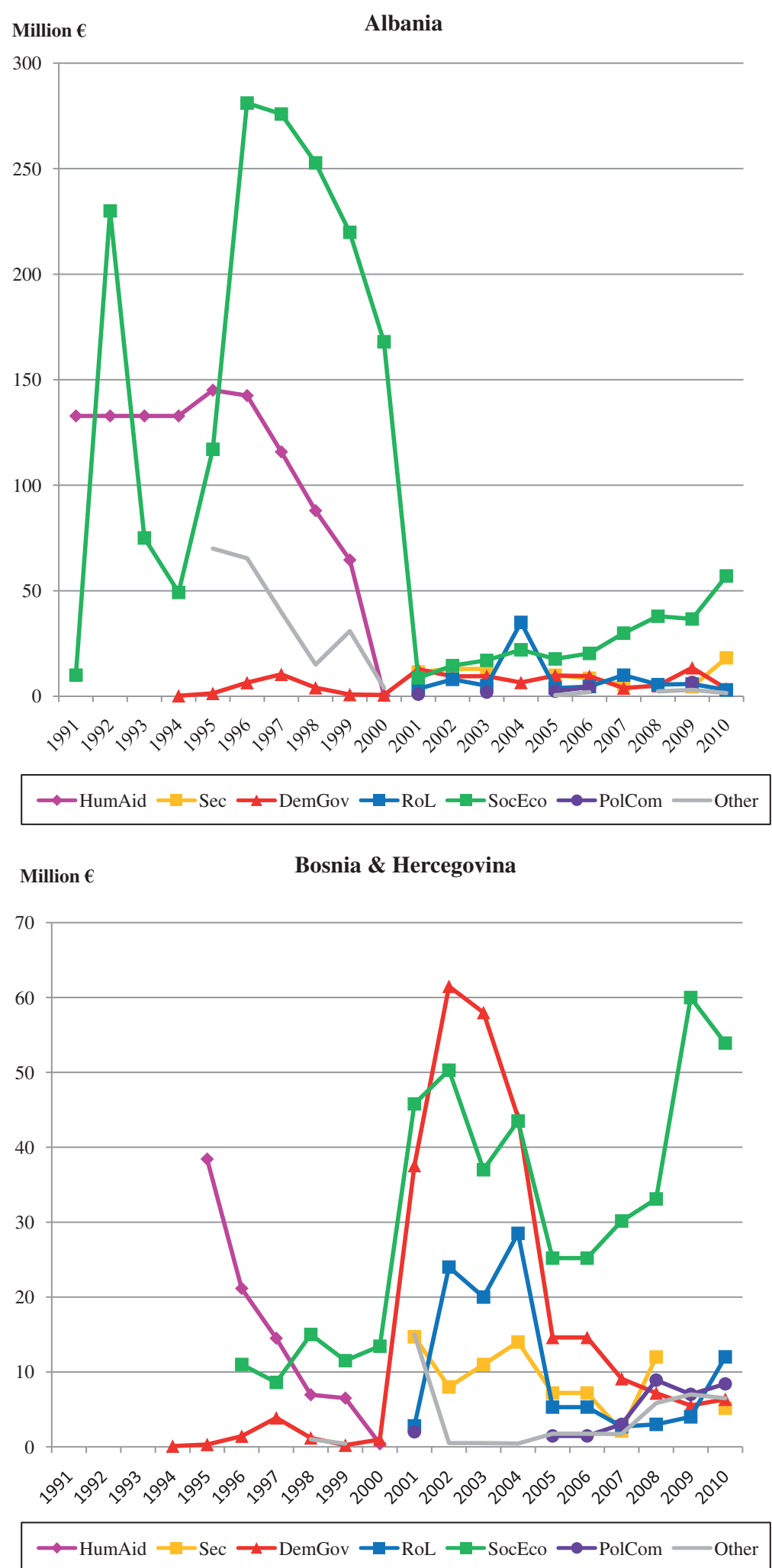

FIGURE 6. 


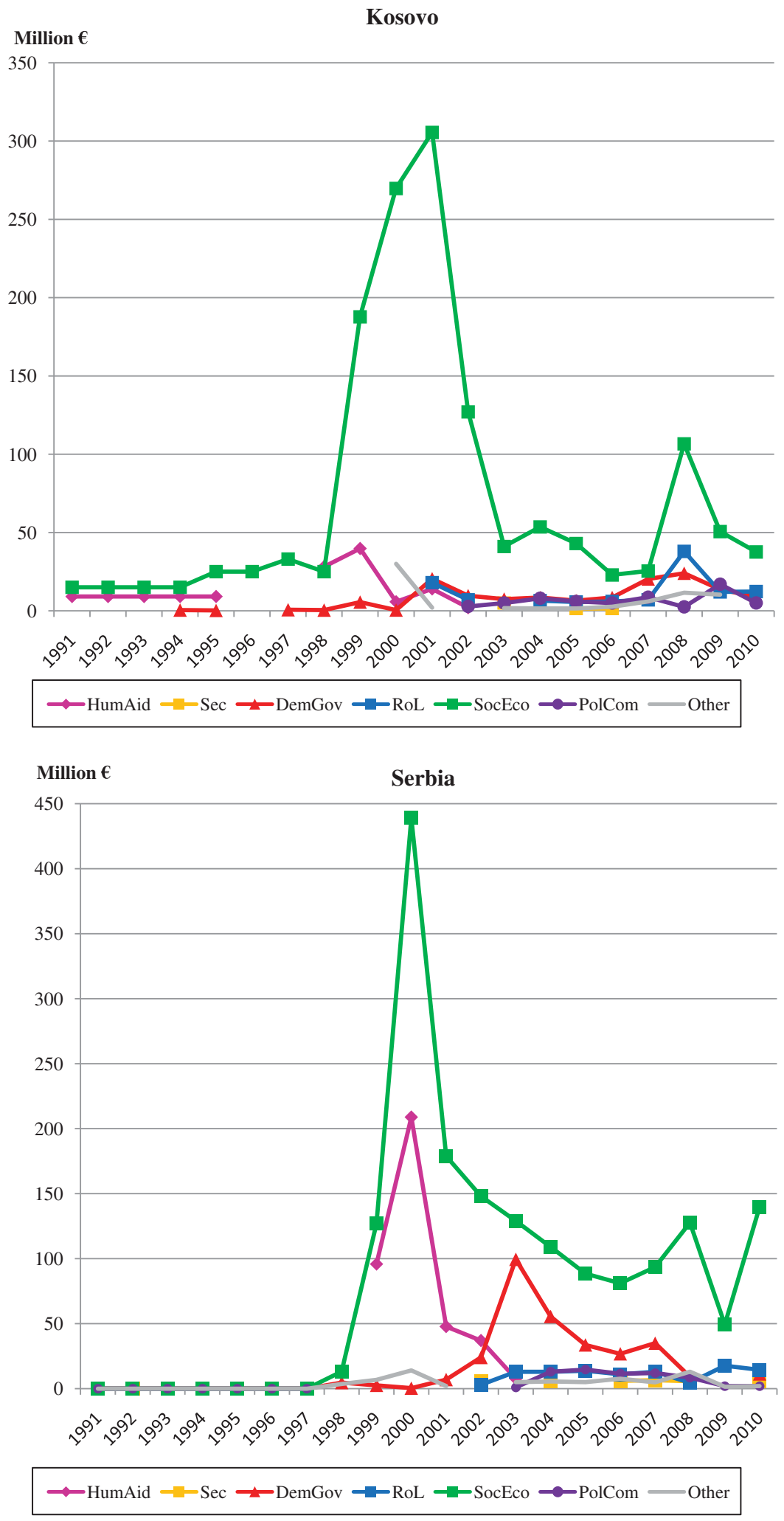

FIGURE 6. EU ASSISTANCE TO POTENTIAL CANDIDATE COUNTRIES.

Notes: HumAid—Humanitarian assistance; Sec—Security; RoL—Rule of law; SocEco-Socio-economic development; DemGov—Democratic governance; PolCom—Political community. Source: Authors' compilation and calculations. 


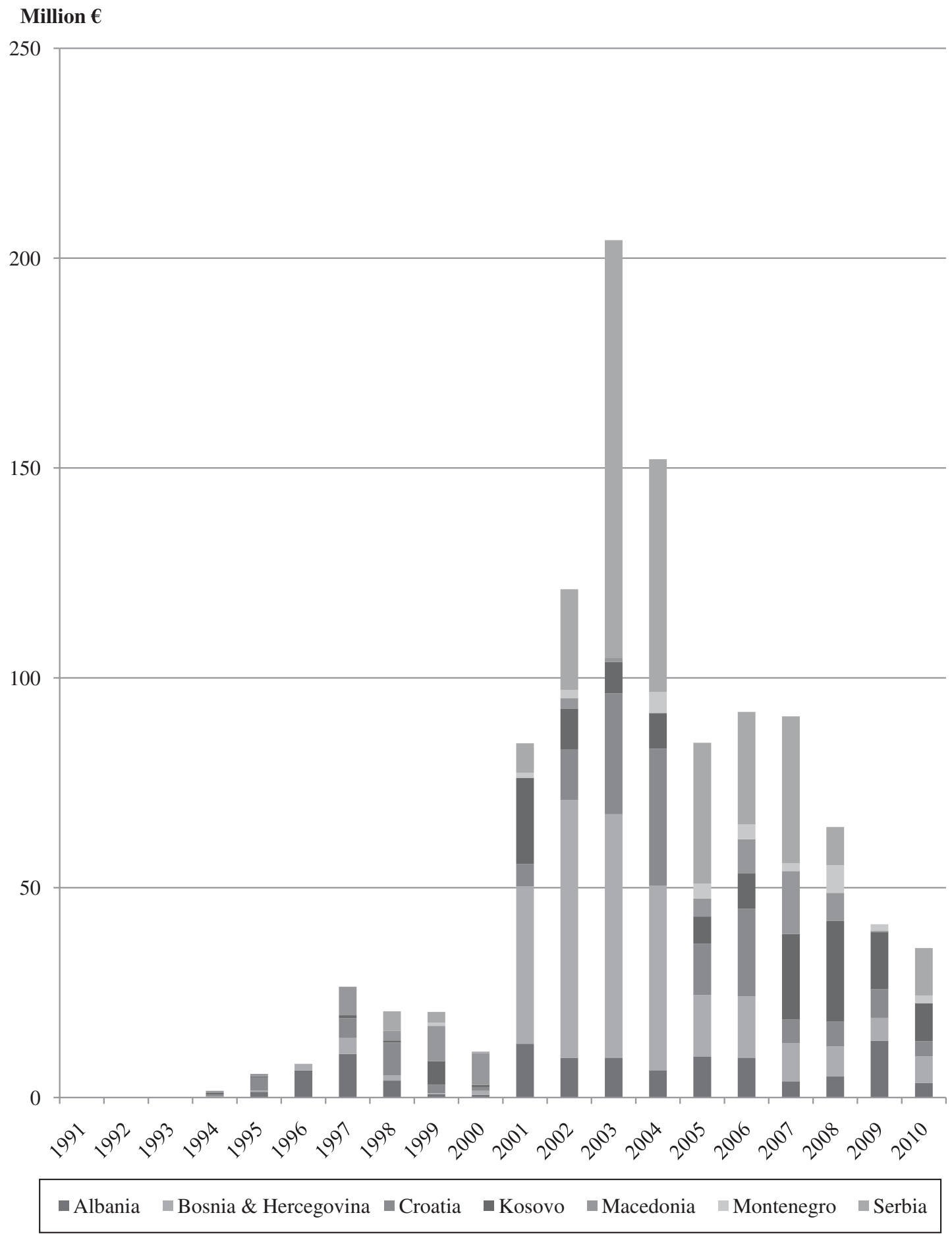

FIGURE 7. EU ASSISTANCE FOR DEMOCRATIC GOVERNANCE. Source: Authors' compilation and calculations.

potential candidate countries has decreased since 2000, even though the EU has officially declared its interest in developing the region and strengthening the countries' capacities to approximate the EU acquis. 


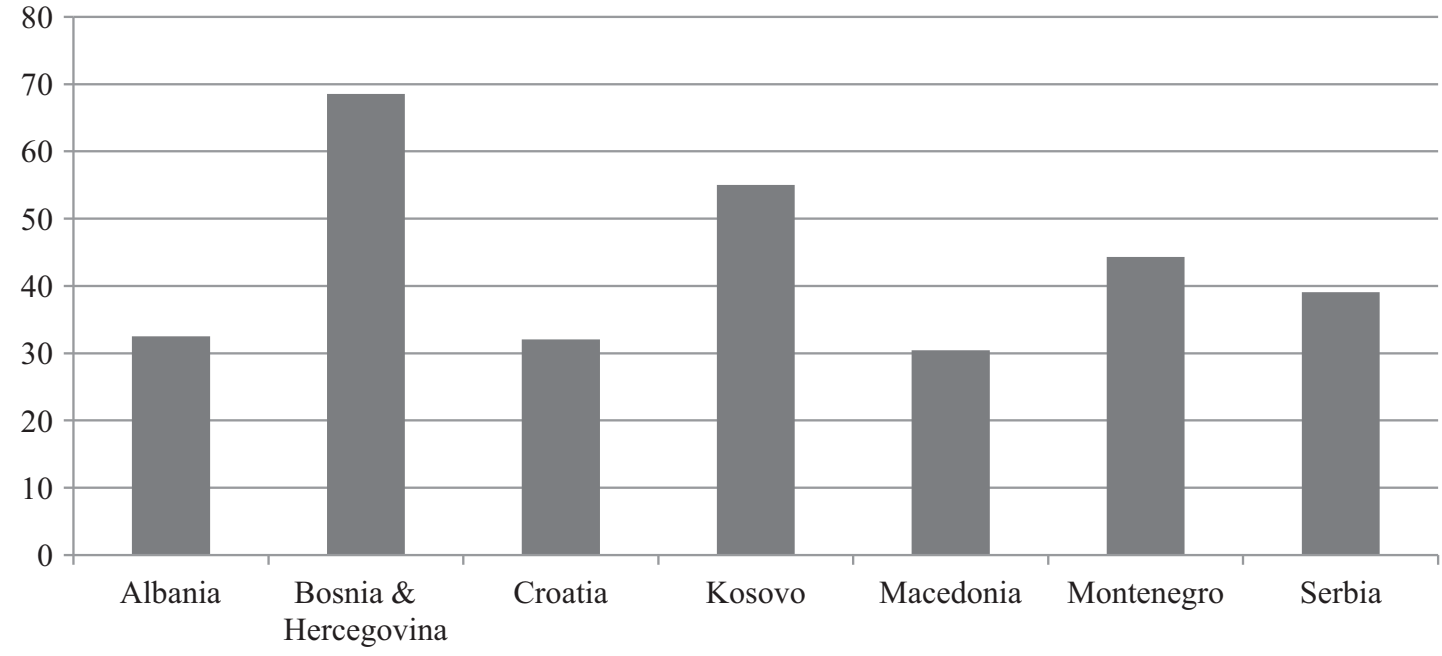

FIGURE 8. EU Assistance for Democratic GOVERnANCE, PER CAPITA, 1991-2010. Note: Based on population averages. Source: Authors' compilation and calculations.

\section{Findings concerning country patterns in democracy assistance}

As our research interest also relates to the particular patterns of providing democracy assistance, we now take a closer look at the democratic governance component and its funding over time. The EU considers itself to be an active democracy promoter in the Western Balkans, although its expenditures have been rather moderate in comparison to assistance in the sector of socio-economic development. Nevertheless, democracy assistance ranks third in the gross spending overview for all categories in the region (see Figure 1).

With regard to sequences and priorities, the accumulated data confirm what our document analysis above has already revealed: assistance in this area started at a rather low level in comparison to other components; it was not the top priority of assistance in the early years of post-conflict recovery. From 1994 onwards, funding to democratic governance was directed to all countries (except for Serbia and Montenegro, who began to receive funding only in 1998-1999). As assessment of the project fiches shows, this early assistance mainly targeted the promotion of a free and independent media. In the late 1990s, Albania was the main recipient of democracy assistance, along with Macedonia and Croatia. After 2000, the year of the Zagreb summit, the figures change drastically. In the four years after the summit, we see an increase in spending in the democratic governance component. In the mid-2000s, spending soared and declined again. In terms of aggregate data, Serbia and Bosnia \& Hercegovina received the most assistance; Croatia, Kosovo and Albania rank in the middle; and Macedonia and Montenegro received the least aid for democratic governance.

The analysis of country patterns indicates that the EU followed a strategy of prioritisation in part according to the 'need' for further democratisation; however, for a short period of time, the EU provided an extra financial push for those countries that were about to gain candidate status (see Figure 7). 
Among the candidate countries, Croatia received the most funding and Montenegro the least. Moreover, one can observe a sequential order: Croatia was one of the focus countries for democracy assistance in the early 2000s, Macedonia followed a few years later, and Montenegro received the least assistance of all countries, although the amount was relatively consistent over time, peaking slightly in 2008. These trends coincide with each country's achievement of candidate status.

The potential candidate countries Serbia and Bosnia \& Hercegovina have clearly been the focus of democracy assistance. This fact is not astonishing, since they are "poor performers' in democratisation. At the same time, there are significant discrepancies between the four potential candidate countries. Serbia received the lion's share of democracy assistance with a peak in 2003 (the year in which then Prime Minister Zoran Djinjic was assassinated), a trend similar to that of Bosnia \& Hercegovina. Kosovo, surprisingly, received relatively little democracy assistance, with highs in 2001 and 2008. In contrast, assistance to Albania was an early priority and evolved quite smoothly over the observation period.

This picture changes slightly if one considers democracy assistance per capita. In this perspective, the most troublesome countries (Bosnia \& Hercegovina and Kosovo) have received per capita most of the EU democracy assistance, whereas Montenegro, Serbia and Albania lag behind (see Figure 8).

In summary, democracy assistance increased after 2000, but remained only the EU's third priority over the entire research period. Among the candidates, Croatia received the most support for democracy assistance; among the potential candidates, Serbia, Bosnia \& Hercegovina and Kosovo received the most democracy assistance funding. However, again, the data do not allow clear identification of a strategic funding pattern concerning democracy assistance.

\section{Conclusions}

As the EU has to date not provided a comprehensive overview of its development and democracy assistance to the Western Balkans on its own initiative, this article has depicted patterns and priorities on the basis of an originally compiled dataset.

In the light of our findings, one can hardly accuse the EU of doing nothing or of being insensitive to the conflict context. We found grosso modo evidence for a sequencing approach that has been adapted to post-conflict contexts: humanitarian assistance came first, socio-economic development second and democracy third. Regarding the Western Balkans, in the short term the EU took into account the special conditions of a post-conflict society. In the long run, it has pursued a developmental approach to democracy promotion, supporting the creation of favourable socio-economic contextual conditions for democratisation. In this regard, EU spending is consistent with official framework programmes. However, we could not identify any strategic funding pattern at the country level—no security-seeking, conflict-preventing, stability-oriented or democracy spill-oversupporting funding patterns could be determined.

With regard to the support of democratic institution-building and capacity-building in particular, funding for this component represented a relatively small share of total EU expenditure in the Western Balkans. In a positive light, one could argue that the EU, not daring to intrude into domestic state affairs, has entrusted the democratisation process to 
local hands. However, it should not be forgotten that the EU has clear criteria for candidate and potential candidate countries to become EU members, especially concerning the standards of democracy and the rule of law. Considering these high standards, according to our empirical findings, the EU does relatively little to directly support the creation of democratic capacity and institutions. Given this finding, it is no surprise that some critics have found classical conditionality to be less effective in the region than expected (Noutcheva 2009; Trauner 2009; Freyburg \& Richter 2010), because the EU has not directly supported the enhancement of domestic capacity financially to address the demands of democratic reform and to manage the democratic transition.

From the perspective of our experience in data sampling, the European Commission does not report its development assistance to the Western Balkans in a transparent and comprehensive manner. Therefore, we wonder on which empirical basis José Manuel Barroso, then President of the European Commission, remarked in 2011 that Kosovo is '[today] the biggest recipient per capita of EU assistance in the whole world' ${ }^{17}$ Taking the whole Western Balkans and a narrow understanding of development assistance into account, our data do not confirm Barroso's claim. However, it remains unclear on which data Barroso based his statement and what concept of 'assistance' he used.

To remedy this situation, our collected data on the EU's financial expenditures in the Western Balkans is a step towards analysing the core areas of cooperation between the EU and its south-eastern neighbours and their respective financial dimensions. In the first place, the data compilation is innovative and systematic itself, allowing a comprehensive overview of the EU's commitment in the region. Moving beyond analytical description, it serves as a starting point for further investigations into specific policy sectors as well as for tracing the effectiveness of EU support.

Regarding democracy promotion, future research should address the following issues which exceed the scope of this article: first, further study could reveal why the percentage of aid spent for democracy assistance is so much lower than aid for other purposes. Is this a result of carefully drafted decision-making reflecting the effectiveness of socio-economic development compared to less effective democracy assistance? Or is it merely the consequence of hasty political actions in response to violent conflicts? Or, do external actors simply shy away from publicly intruding into domestic political affairs? Second, it is necessary to assess whether and to what extent the allocated amount of democracy assistance is sufficient for supporting democratisation. Clearly, enhancing the capacity to manage the democratisation reform project is necessary for countries to succeed in this task. However, we still know very little about how much assistance is required to guarantee the survival of democratic institutions that have been intensively financially supported from the outside. Third, clarification is needed as to what extent financial flows reflect the political conditionality policy of the EU towards the region. Here, the various democracy promotion instruments should be examined in combination to reveal whether the instruments are implemented to their mutual benefit or detriment. Finally, inter-regional comparisons and comparisons to aid supplied by other donors could shed light on different aid strategies and would allow generalisation of the conditions for the successful external support of transition in post-conflict contexts. It is precisely the combination of high complexity and

\footnotetext{
17 'Statement by President José Manuel Barroso following his meeting with Hashim Thaçi, Prime Minister of Kosovo', Speech/11/360, Press Point, Pristina, 20 May 2011, available at: http://europa.eu/rapid/pressrelease_SPEECH-11-360_en.htm?locale=en, accessed 15 May 2015.
} 
unsatisfactory transparency of the EU aid architecture regarding the Western Balkans that makes further investigations so challenging, but indispensable.

\section{University of Konstanz}

German Development Institute, Bonn

\section{References}

Acemoglu, D., Robinson, J. A., Johnson, S. \& Yared, P. (2009) ‘Reevaluating the Modernization Hypothesis’, Journal of Monetary Economics, 56, 8.

Altenburg, T. \& Leininger, J. (2008) 'Global Shifts Caused by the Rise of Anchor Countries', Zeitschrift für Wirtschaftsgeographie, 52, 1.

Anastasakis, O. (2008) 'The EU's Political Conditionality in the Western Balkans: Towards a More Pragmatic Approach', Journal of Southeast European and Black Sea Studies, 8, 4.

Ballentine, K. \& Sherman, J. (eds) (2004) The Political Economy of Armed Conflict: Beyond Greed and Grievance (Boulder, CO, Lynne Rienner).

Bebler, A. (2002) 'Slovenia's Smooth Transition', Journal of Democracy, 13, 1.

Bukowski, C. (1999) 'Slovenia's Transition to Democracy: Theory and Practice', East European Quarterly, $33,1$.

Burnell, P. (2000) 'Democracy Assistance. The State of the Discourse', in Burnell, P. (ed.) Democracy Assistance. International Co-operation for Democratization (London, Frank Cass).

Calic, M.-J. (1996) Krieg und Frieden in Bosnien-Hercegovina (Frankfurt, Suhrkamp).

Caplan, R. (2005) International Governance of War-Torn Territories. Rule and Reconstruction (Oxford, Oxford University Press).

Carothers, T. (1999) Aiding Democracy Abroad. The Learning Curve (Washington, DC, Brookings Institution Press).

Carothers, T. (2009) 'Democracy Assistance. Political vs. Developmental?', Journal of Democracy, 20, 1.

Cerar, M. (2001) 'Slovenia. From Elite Consensus to Democratic Consolidation', in Zielonka, J. (ed.) Democratic Consolidation in Eastern Europe. Volume I. Institutional Engineering (Oxford, Oxford University Press).

Chandler, D. (2000) Bosnia. Faking Democracy after Dayton (London, Pluto Press).

Chesterman, S., Ignatieff, M. \& Thakur, R. C. (eds) (2005) Making States Work. State Failure and the Crisis of Governance (Tokyo, United Nations University Press).

Coggins, B. (2011) 'Friends in High Places: International Politics and the Emergence of States from Secessionism', International Organization, 65, 3.

Collier, P. (2000) 'Doing Well out of War. An Economic Perspective', in Berdal, M. R. \& Malone, D. M. (eds) Greed \& Grievance. Economic Agendas in Civil Wars (Boulder, CO, Lynne Rienner).

Collier, P. \& Hoeffler, A. (2004) 'Greed and Grievance in Civil War', Oxford Economic Papers, 56, 4.

Dahl, R. A. (1971) Polyarchy. Participation and Opposition (New Haven, CT, \& London, Yale University Press).

European Agency for Reconstruction (2001-2008) 'Where We Work/Annual Programmes', European Agency for Reconstruction, available at: http://ec.europa.eu/enlargement/archives/ear/home/default. htm, accessed 1 March 2012.

European Commission (2001) 'External Relations Directorate General: CARDS Assistance Programme to the Western Balkans', Regional Strategy Paper 2002-2006, available at: http://ec.europa.eu/enlargement/ pdf/financial_assistance/cards/publications/regional_strategy_paper_en.pdf, accessed 1 March 2012.

European Commission (2010) 'Funding', DG Humanitarian Aid, available at: http://ec.europa.eu/echo/ funding/finances_en.htm, accessed 1 March 2012.

European Commission (2011a) 'The Stabilization and Association Process', DG Enlargement, available at: http://ec.europa.eu/enlargement/enlargement_process/accession_process/how_does_a_country_join_ the_eu/sap/index_en.htm, accessed 1 March 2012.

European Commission (2011b) 'CARDS Reports and Publications', DG Enlargement, available at: http://ec. europa.eu/enlargement/press_corner/key-documents/CARDS_reports_and_publications_en.htm, accessed 1 March 2012.

European Commission (2011c) 'Instrument for Pre-Accession Assistance (IPA)', DG Enlargement, available at: http://ec.europa.eu/enlargement/how-does-it-work/financial-assistance/instrument-pre-accession_en. htm, accessed 1 March 2012. 
European Commission (2011d) 'Assistance to Candidate Countries', DG Enlargement, available at: http://ec. europa.eu/enlargement/candidate-countries/index_en.htm, accessed 1 March 2012.

European Commission (2011e) 'Assistance to Potential Candidate Countries', DG Enlargement, available at: http://ec.europa.eu/enlargement/potential-candidates/index_en.htm, accessed 1 March 2012.

European Commission (2011f) 'Funding', DG Development, available at: http://ec.europa.eu/europeaid/ work/funding/index_en.htm, accessed 23 May 2011.

European Commission (2011g) 'European Commission Directorate General on Development and Cooperation-EuropeAid', DG Development, available at: http://ec.europa.eu/europeaid/index_en. htm, accessed 1 March 2012.

European Communities (2003) 'The Road to Integration-the European Union and the Western Balkans', available at: http://ec.europa.eu/enlargement/pdf/financial_assistance/CARDS/publications/gl_2003_ en.pdf, accessed 1 March 2012.

European Council (1989) Council Regulation (EEC) No 3906/89 on Economic Aid to the Republic of Hungary and the Polish People's Republic, 18 December, available at: http://eur-lex.europa.eu/legalcontent/EN/TXT/?uri=CELEX:31989R3906, accessed 15 May 2015.

European Council (1990) Council Regulation (EEC) No 2698/90 Amending Regulation 3906/89 in Order to Extend Economic Aid to Other Countries of Central and Eastern Europe, 17 September, available at: http://eur-lex.europa.eu/legal-content/EN/TXT/?uri=CELEX:31990R2698, accessed 15 May 2015.

European Council (1991) Council Regulation (EEC) No 3800/91 Amending Regulation (EEC) No 3906/89 in Order to Extend Economic Aid to Other Countries of Central and Eastern Europe, 23 December, available at: http://eur-lex.europa.eu/legal-content/EN/TXT/?uri=CELEX:31991R3800, accessed 15 May 2015.

European Council (1996a) Council Regulation (EC) No 463/96 Amending Regulation (EEC) No 3906/89 with a View to Extending Economic Assistance to the Former Yugoslav Republic of Macedonia, 11 March, available at: http://eur-lex.europa.eu/legal-content/EN/TXT/?uri=CELEX:31996R0463, accessed 15 May 2015.

European Council (1996b) Council Regulation (EC) 1628/1996 Relating to Aid for Bosnia and Herzegovina, Croatia, the Federal Republic of Yugoslavia and the Former Yugoslav Republic of Macedonia, 25 July, available at: http://publications.europa.eu/en/publication-detail/-/publication/f0b06b39-8f1a-419ca6e2-a4a8ea6a1d16/language-de/format-PDFA1B, accessed 15 May 2015.

European Council (1996c) Council Regulation (EC) No 1257/1996 Concerning Humanitarian Aid, 20 June, available at: http://eur-lex.europa.eu/legal-content/EN/TXT/HTML/?uri=CELEX:31996R1257\& from $=\mathrm{EN}$, accessed 15 May 2015.

European Council (1999a) Council Regulation (EC) No 1266/1999 on Coordinating Aid to the Applicant Countries in the Framework of the Pre-accession Strategy and Amending Regulation (EEC) No 3906/89, 21 June, available at: http://eur-lex.europa.eu/legal-content/GA/TXT/?uri=CELEX:31999R1266, accessed 15 May 2015

European Council (1999b) Council Regulation (EC) 975/1999 Laying Down the Requirements for the Implementation of Development Cooperation Operations which Contribute to the General Objective of Developing and Consolidating Democracy and the Rule of Law and to that of Respecting Human Rights and Fundamental Freedoms, 29 April, available at: http://eur-lex.europa.eu/legal-content/EN/TXT/? uri=CELEX:31999R0975, accessed 15 May 2015.

European Council (1999c) Council Regulation (EC) 976/1999 Laying Down the Requirements for the Implementation of Community Operations, other than those of Development Cooperation, which, within the Framework of Community Cooperation Policy, Contribute to the General Objective of Developing and Consolidating Democracy and the Rule of Law and to that of Respecting Human Rights and Fundamental Freedoms in Third Countries, 29 April, available at: http://eur-lex.europa.eu/legal-content/ EN/TXT/?qid=1431945624568\&uri=CELEX:31999R0976, accessed 15 May 2015.

European Council (2000) Council Regulation (EC) No 2666/2000 on Assistance for Albania, Bosnia and Herzegovina, Croatia, the Federal Republic of Yugoslavia and the Former Yugoslav Republic of Macedonia, Repealing Regulation (EC) No 1628/96 and Amending Regulations (EEC) No 3906/89 and (EEC) No 1360/90 and Decisions 97/256/EC and 1999//311/EC, 5 December, available at: http://eur-lex. europa.eu/legal-content/EN/TXT/?qid=1431945874113\&uri=CELEX:32000R2666, accessed 15 May 2015.

European Council (2006) Council Regulation (EC) 1889/2006 of the European Parliament and of the Council on Establishing a Financing Instrument for the Promotion of Democracy and Human Rights Worldwide, available at: http://eur-lex.europa.eu/legal-content/EN/TXT/?uri=CELEX:32006R1889, 20 December, accessed 15 May 2015.

European Union (2007) 'Summaries of EU Legislation: CARDS Programme (2000-2006)', available at: http://europa.eu/legislation_summaries/enlargement/western_balkans/r18002_en.htm, accessed 1 March 2012. 
European Union (2011a) 'European Union Policy Areas, Humanitarian Aid', available at: http://europa.eu/ pol/hum/index_en.htm, accessed 1 March 2012.

European Union (2011b) 'European Union External Action: EU Delegations', available at: http://eeas.europa. eu/delegations/web_en.htm, accessed 1 March 2012.

European Union External Action Service (2012) EULEX Kosovo Factsheet, available at: http://eeas. europa.eu/csdp/missions-and-operations/eulex-kosovo/pdf/12102012_factsheet_eulex-kosovo_en.pdf, accessed 10 November 2013.

Freyburg, T. \& Richter, S. (2010) 'National Identity Matters. The Limited Impact of EU Political Conditionality in the Western Balkans', Journal of European Public Policy, 17, 2.

Grabbe, H. (2005) The EU's Transformative Power. Europeanization through Conditionality in Central and Eastern Europe (New York, NY, Palgrave Macmillan).

Grävingholt, J., Leininger, J. \& Schlumberger, O. (2009) The Three Cs of Democracy Promotion Policy. Context, Consistency and Credibility (Bonn, Deutsches Institut für Entwicklungspolitik).

Grimm, S. (2008) 'External Democratization after War. Success and Failure', Democratization, 15, 3.

Grimm, S. (2010) Erzwungene Demokratie. Politische Neuordnung nach militärischer Intervention unter externer Aufsicht (Baden-Baden, Nomos).

Grimm, S. (2014) 'The European Union's Ambiguous Concept of "State Fragility", Third World Quarterly, $35,2$.

Grimm, S. \& Leininger, J. (2012) 'Not All Good Things Go Together. Conflicting Objectives in Democracy Promotion', Democratization, 19, 3.

Gromes, T. (2009) 'A Case Study in "Institutionalisation before Liberalisation”. Lessons from Bosnia and Herzegovina', Journal of Intervention and Statebuilding, 3, 1.

Gross, L. \& Grimm, S. (2014) 'The External-Domestic Interplay in Democracy Promotion: A Case Study on Public Administration Reform in Croatia', Democratization, 21, 5.

Hyde-Price, A. (2006) “"Normative” Power Europe: A Realist Critique', Journal of European Public Policy, $13,2$.

Linz, J. J. \& Stepan, A. (1996) “'Stateness”, Nationalism, and Democratization’, in Linz, J. \& Stepan, A. (eds) Problems of Democratic Transitions and Consolidation (Baltimore, MD, Johns Hopkins University Press).

Manners, I. (2002) 'Normative Power Europe: A Contradiction in Terms?', Journal of Common Market Studies, 40, 2.

Manners, I. (2006) 'Normative Power Europe Reconsidered: Beyond the Crossroads', Journal of European Public Policy, 13, 2.

Narten, J. (2008) 'Post-Conflict Peacebuilding and Local Ownership. Dynamics of External-Local Interaction in Kosovo under United Nations Administration', Journal of Intervention and Statebuilding, 2,3 .

Noutcheva, G. (2009) 'Fake, Partial and Imposed Compliance. The Limits of the EU's Normative Power in the Western Balkans', Journal of European Public Policy, 16, 7.

OECD (2013) 'Statistics: ODA Flows by Donor', Organisation for Economic Coordination and Development, available at: http://stats.oecd.org/, accessed 23 December 2013.

Pace, M. (2007) 'The Construction of EU Normative Power', Journal of Common Market Studies, 45, 5.

Pond, E. (2006) Endgame in the Balkans. Regime Change, European Style (Washington, DC, Brookings Institution Press).

Przeworski, A. \& Limongi, F. (1997) 'Modernization. Theories and Facts', World Politics, 49, 1.

Rotberg, R. I. (ed.) (2004) When States Fail. Causes and Consequences (Princeton, NJ, Princeton University Press).

Schimmelfennig, F. (2008) 'EU Political Accession Conditionality after the 2004 Enlargement. Consistency and Effectiveness', Journal of European Public Policy, 15, 6.

Schimmelfennig, F. \& Sedelmeier, U. (2004) 'Governance by Conditionality. EU Rule Transfer to the Candidate Countries of Central and Eastern Europe', Journal of European Public Policy, 11, 4.

Spanger, H.-J. \& Wolff, J. (2007) 'Universales Ziel-partikulare Wege? Externe Demokratieförderung zwischen einheitlicher Rhetorik und vielfältiger Praxis', in Geis, A., Müller, H. \& Wagner, W. (eds) Schattenseiten des Demokratischen Friedens. Zur Kritik einer Theorie liberaler Außen- und Sicherheitspolitik (Frankfurt, Campus).

Stability Pact (2005) 'About the Stability Pact', The Stability Pact for South Eastern Europe, available at: http://www.stabilitypact.org/, [weblink no longer active] accessed 1 March 2012.

Stamm, A. (2004) Schwellen- und Ankerländer als Akteure einer globalen Partnerschaft DIE Discussion Paper 1/2004 (Bonn, Deutsches Institut für Entwicklungspolitik).

Tansey, O. (2007) 'Democratization without a State. Democratic Regime-building in Kosovo', Democratization, 14, 1. 
Trauner, F. (2009) 'From Membership Conditionality to Policy Conditionality. EU External Governance in South Eastern Europe', Journal of European Public Policy, 16, 5.

Van Hüllen, V. \& Stahn, A. (2009) 'Comparing EU and US Democracy Promotion in the Mediterranean and the Newly Independent States', in Magen, A., Risse, T. \& McFaul, M. A. (eds) Promoting Democracy and the Rule of Law. American and European Strategies (London, Palgrave Macmillan).

Walter, B. F. (1997) 'The Critical Barrier to Civil War Settlement', International Organization, 51, 3.

Walter, B. F. (2004) 'Does Conflict Beget Conflict? Explaining Recurring Civil War', Journal of Peace Research, 41, 3.

Woodward, S. L. (1995) Balkan Tragedy. Chaos and Dissolution after the Cold War (Washington, DC, The Brookings Institution).

Youngs, R. (2011) 'The End of Democratic Conditionality: Good Riddance?', in Haynes, J. (ed.) The Routledge Handbook of Democratization (London, Routledge).

Zaum, D. (2007) The Sovereignty Paradox. The Norms and Politics of International Statebuilding (Oxford, Oxford University Press).

Zeeuw, J. D. \& Kumar, K. (eds) (2006) Promoting Democracy in Postconflict Societies (Boulder, CO, Lynne Rienner). 